\title{
Twixt Candle and Lamp: The Contribution of Elizabeth Fry and the Institution of Nursing Sisters to Nursing Reform
}

\author{
R G HUNTSMAN, MARY BRUIN and DEBORAH HOLTTUM*
}

In 1897, to commemorate the Diamond Jubilee of Queen Victoria's reign, a leading article appeared in the British Medical Journal entitled 'The nursing of the sick under Queen Victoria'.' Outlining the evolution of nursing, it described Elizabeth Fry as "the founder of nursing". For the author of an article in the Nursing Record and Hospital World in the same year, ${ }^{2}$ she was "the real pioneer of Nursing in this country". In the light of such unusual agreement between doctors and nurses, it is curious that a hundred years later, Elizabeth Fry's contribution to the founding of the nursing profession is, with very few exceptions, almost totally forgotten. ${ }^{3}$ The purpose of this article is to assess whether these claims were valid and, if so, why they are no longer widely recognized today.

Elizabeth was born in 1780 in Norwich into a wealthy Quaker family, the fourth of twelve children of John Gurney, a Norfolk banker. ${ }^{4}$ Being dyslexic, she was considered by her family to be stupid and was unable to benefit fully from the

* R G Huntsman, MD, FRCP, FRCPath, The Institute of Social and Economic Research, Memorial University, St John's Newfoundland, Canada A1C 5S7. Address for correspondence: Australind, Brancaster Staithe, King's Lynn, Norfolk, PE31 8BP, UK; Mary Bruin, BA, 14 Marshall Drive, Hayes, Middlesex, UB4 OSW; Deborah Holttum, 300 Malden Road, New Malden, Surrey, KT3 6AT.

For this article we have drawn extensively on the records of the Institution of Nursing Sisters which are held with the records of the Queen's Nursing Institute in the Archives and Manuscripts collections of the Wellcome Library, London, shelfmark SA/QNI. Unless otherwise stated, the unpublished material cited is from this collection. We have also had access to Elizabeth Fry's unpublished journals and other archives held in the Religious Society of Friends' Library, London. We are especially grateful to the staff of these two libraries for their help. We should also like to thank the editors of Medical History for their editorial comments and suggestions.

\footnotetext{
${ }^{1}$ Editorial, 'The nursing of the sick under Queen Victoria', Br. med. J., 1897, i: 1644-8, p. 1645 .

${ }^{2}$ Margaret Breay, 'Nursing in the Victorian era', The Nursing Record and Hospital World, 1897, 18: 493-502, p. 493.

${ }^{3}$ Katherine Williams, 'From Sarah Gamp to Florence Nightingale: a critical study of hospital nursing systems from 1840 to 1897', in C Davies (ed.), Rewriting nursing history, New Jersey, Barnes and Noble Books, 1980, pp. 41-75, pp. 43, 49; Anne Summers, Female lives, moral states: women, religion and public life in Britain 1800-1930, Newbury, Threshold Press, 2000, pp. 81-84, 100-16.

${ }^{4}$ Katherine Fry and Rachel Elizabeth Cresswell, Memoir of the life of Elizabeth Fry: with extracts from her journals and letters, 2nd ed., 2 vols, London, John Hatchard and Son, 1848; reprinted, Patterson Smith Publishing Corporation, Montclair, New Jersey, 1974, Series in Criminology, Law Enforcement and Social Problems, no.187, vol. 1, Elizabeth Fry's Gurney ancestry, Plate 1 (Introduction).
} 


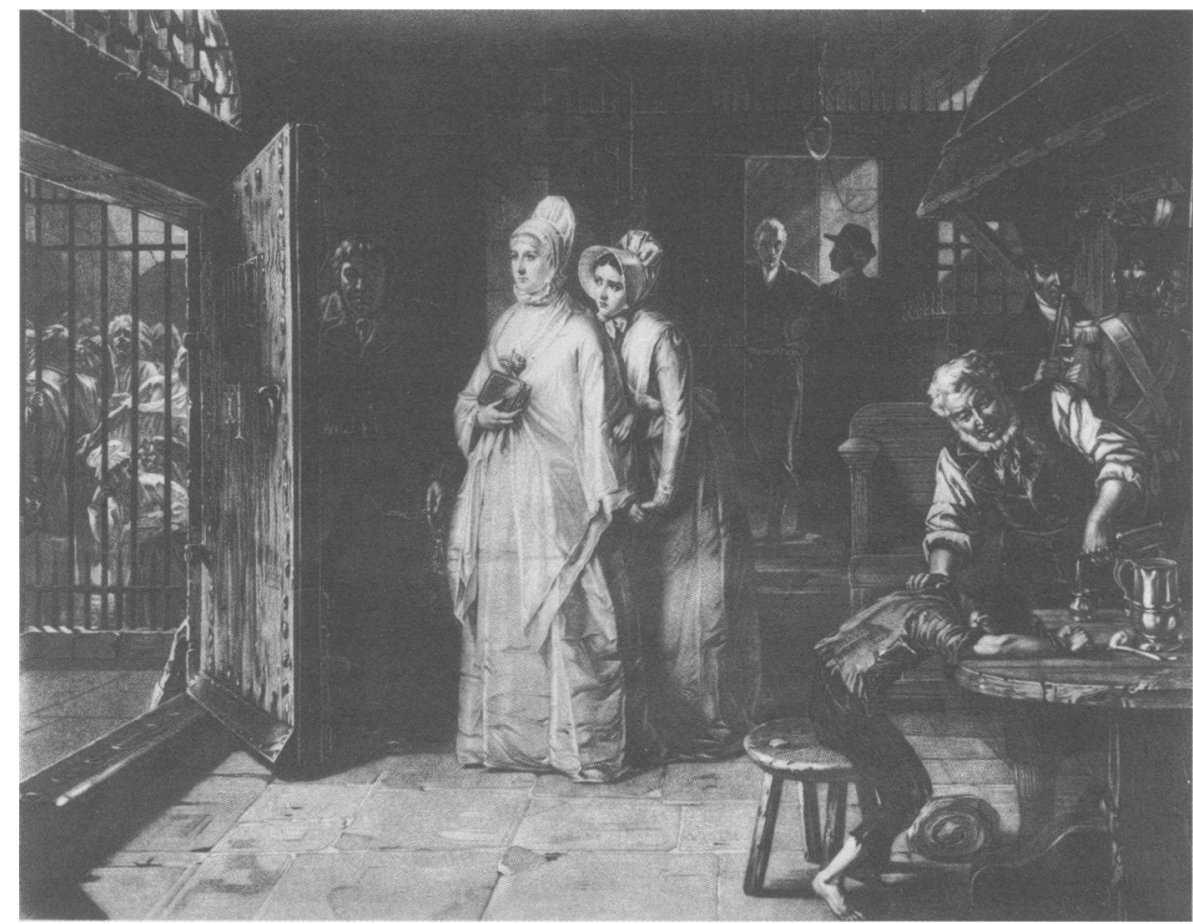

Figure 1: Elizabeth Fry, accompanied by Mary Sanderson, visits Newgate Prison. Elizabeth Fry is now remembered solely for her work on penal reform. Her many other philanthropic activities such as nursing reform, establishing savings societies for the poor, and setting up libraries for the blockade men (coastguard) and the navy are now forgotten. Painting by Henrietta Mary Ward, 1895. Reproduction courtesy of the Library Committee, Religious Society of Friends, London.

excellent education that Quakers offered to both their male and female children. ${ }^{5}$ From an early age, like many in her social position at that time, she participated in philanthropic activities, visiting the local sick and setting up a school in the laundry of her family's large home. She personally vaccinated the local children and, as a result, smallpox was scarcely known in the villages over which her influence extended. ${ }^{6}$

After her marriage to Joseph Fry, she moved to central London and in 1813 she first visited Newgate Prison (see Figure 1). ${ }^{7}$ The appalling conditions of the female prisoners triggered her commitment to penal reform. For the rest of her life, she travelled widely throughout the British Isles and Continental Europe inspecting prisons and advising on their management.

Elizabeth Fry had eleven children and suffered from postpartum depression. Throughout her life, she had severe attacks of toothache, for which leeches were

\footnotetext{
${ }^{5} \mathrm{R}$ G Huntsman and T M Miles, 'The stupidity of Elizabeth Fry: was she dyslexic?', forthcoming.
}

\footnotetext{
${ }^{6}$ Fry and Cresswell, op. cit., note 4 above, vol. 1 , p. 170.

${ }^{7}$ Ibid., vol. 1, pp. 200-3.
} 


\section{The Contribution of Elizabeth Fry to Nursing Reform}

applied to the gums, an experience she described as "rather unpleasant". Fearing an extraction without an anaesthetic, not surprisingly, she turned, like many others, to laudanum and gin, the accepted analgesics of that era, for relief from her pain. ${ }^{8}$

Tuberculosis was endemic in both the Gurney and the Fry families, and from childhood, Elizabeth Fry had a chronic cough with intermittent episodes of weakness, fatigue and fever, and, not unnaturally, fear of "my present lung complaint" preyed on her mind. In 1824, like her two sisters who died of pulmonary tuberculosis, she was sent for three months to Brighton for bed rest by the sea. Four years later, she reported that she was coughing up "a little blood". ${ }^{9}$ For a number of years before her death she was unwell, suffering from "much pain, and helplessness, and incapability of active occupation". A family friend, Frances, Baroness Bunsen, describing her death, wrote "she fell down insensible and expired next morning. It is believed to have been the dropsy, which was gaining ground upon her, and threatened lingering pain, which suddenly affected the brain". ${ }^{10}$ Throughout her life, even during adolescence, Elizabeth Fry enjoyed wine and porter, a strong, stout-like beer, and it has been suggested that this led to alcohol dependence. ${ }^{11}$ Her death certificate of 1845 gives the cause of death as "Serous Effusion in the Brain 26 hours. Partial Paralysis $1 \frac{1}{2}$ Year".

During her life she was disappointed that many of her children married outside the Quaker faith that meant so much to her. She also had to suffer the disgrace that followed the collapse of her husband's banking business. ${ }^{12}$ It is against this background of dyslexia, ill health and personal misfortunes that the remarkable achievements of Elizabeth Fry are to be measured.

\section{The Evolution of Nursing Care}

In France in 1630, St Vincent de Paul established the Filles de Charité, later known as the Sisters of Charity. He found that village girls were best suited to the work of hospital nurses..$^{13}$ His action was revolutionary because, with few exceptions, up to that time women joining Catholic sisterhoods were expected to remain within the shelter of the cloister.

By contrast to Catholic countries, in England the dissolution of the monasteries by Henry VIII in 1536 had brought to an end the care of the sick by religious orders, and nursing entered a dark age. The sole survival of "Romanism" in Britain appears to be the courtesy title of "Sister" that continued to be bestowed on the head nurse

\footnotetext{
${ }^{8} \mathrm{H}$ M Thomas, 'Elizabeth Fry: Quaker reformer', Johns Hopkins Hosp. Bull., 1919, 30: 72-80, p. 78; Elizabeth Fry, Journals, 26 Sept. 1799, 13 Sept. 1798; 27 Sept. 1799.

${ }^{9}$ Fry and Cresswell, op. cit., note 4 above, vol. 1, pp. 241, 450-62; Fry, Journals, 14 Dec. 1828.

${ }^{10}$ Augustus J C Hare, The life and letters of Frances Baroness Bunsen, 2 vols, London, Daldy, Isbister, 1879, vol. 2, p. 83; Frances,
}

Baroness Bunsen, A memoir of Baron Bunsen, 2 vols, London, Longmans, Green, 1868, vol. 2, p. 96.

${ }^{11}$ Fry, Journals, 6 Mar., 1799; June Rose, Elizabeth Fry, London, Macmillan, 1980, p. 137.

${ }^{12}$ Fry and Cresswell, op. cit., note 4 above, vol. 2, pp. 30, 99-100, 110-12, 32-7.

${ }^{13}$ Sioban Nelson, 'The modern nurse in 17th century France', Nursing Hist. Rev., 1999, 7: 171-87, p. 182. 
of a ward, even in Protestant hospitals. ${ }^{14}$ Well after London had witnessed the antiCatholic Gordon Riots in 1780, antagonism verging on hatred between Protestant and Catholic festered on. As a result, any nursing sister suspected of Catholicism risked being attacked by the public. ${ }^{15}$ To prevent mistaken identity, the Protestant nursing order subsequently established in Germany at Kaiserswerth (in 1836) wore blue uniforms, ${ }^{16}$ and the Institution of Nursing Sisters founded in London (in 1840) by Mrs Fry wore dark brown. A sample of the material used for the dresses of the latter is still attached to the minutes of their Ladies' Committee. It was in part thanks to Catholic and Protestant nursing sisters working together as a single unit in the Crimean War (1854-6), that attitudes changed and the persecution began to abate. ${ }^{17}$ Before then, Catholic nursing orders had little positive influence on the usually poor nursing standards in Britain. It was only through curious visitors or on the battlefield that their work became known across the Channel.

Prior to the industrial revolution, it was customary for both rich and poor to be nursed and, if need be, to die in their own homes. In 1854, Florence Nightingale stated: "The family tie is so strong as to induce the best to keep their sick at home, unless there be something in the character of these sick which impels the family to try to get rid of the burden" ${ }^{18}$ In 1865 , a member of the Committee of the Liverpool Nurses' Training School wrote, "I suppose everyone will agree with me that every sick man (or woman) is better at home, if only he (or she) could have the same medical treatment and nursing there that he (or she) would have in a hospital". ${ }^{19}$ The hospital and workhouse infirmary came into prominence primarily to serve the needs of the rapidly increasing urban poor that resulted from the industrial revolution. This movement of population, and the desperate housing conditions that followed, caused the number of hospital patients in England and Wales to increase in the first half of the nineteenth century from 3,000 to nearly $8,000 .{ }^{20}$ The radical changes in nursing that took place in Britain were a response to this shift in the pattern of health care requirement and the developing recognition of the need for competent private and hospital nursing staff.

Through his portrayal of Sarah Gamp and Betsey Prig in Martin Chuzzlewit, Dickens caricatured the nursing care likely to be provided in 1844 in private homes as well as in many hospitals. Mrs Gamp, the better known of the two, was a monthly nurse and midwife, who augmented her income by laying out the dead, filling her remaining spare time as a private night nurse. She would request her clients to "leave the bottle on the chimley-piece and let me put my lips to it when I am so dispoged".

\footnotetext{
${ }^{14} \mathrm{~J}$ M Ludlow, Woman's work in the church, London, Alexander Strahan, 1865, p. 203.

${ }^{15} M$ Adelaide Nutting and Lavinia L Dock, $A$ history of nursing, 4 vols, New York and London, G P Putnam's Sons, 1907, vol. 2, p. 98.

${ }^{16}$ Elizabeth Gurney, Elizabeth Fry's journeys on the continent, 1840-1841, ed. R Brimley Johnson, London, John Lane, The Bodley Head, 1931, pp. $61,138$.

${ }^{17}$ Allan T Cameron, The religious communities of the church of England, London, Faith Press, 1918, pp. 18-19.
}

\footnotetext{
${ }^{18}$ Harry Verney, Florence Nightingale at Harley Street, London, J M Dent, 1970, p. 16.

${ }^{19}$ Member of the Committee of the Home and Training School with an Introduction and Notes by Florence Nightingale, Organisation of nursing: an account of the Liverpool Nurses' Training School, its foundation, progress, and operation in hospital, district and private nursing, Liverpool, A Holden; and London, Longman, Green, Reader and Dyer, 1865, p. 26.

${ }^{20}$ Brian Abel-Smith, The hospitals, 1800-1948, London, Heinemann, 1964, p. 16.
} 


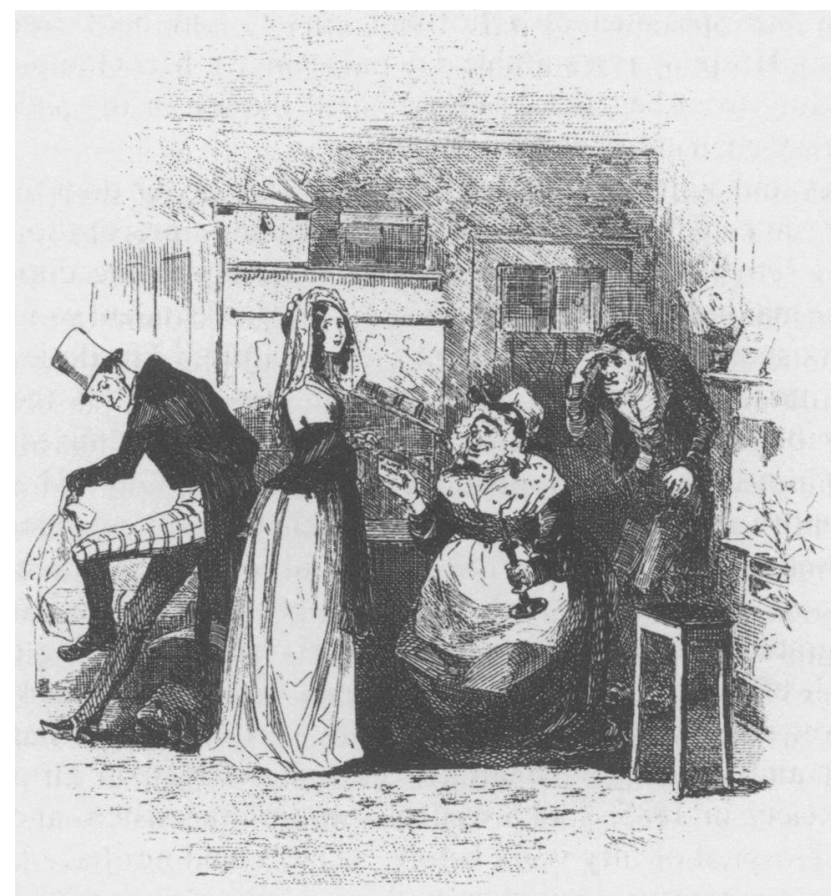

Figure 2: Candle in hand, Sarah Gamp prepares to supplement her income by a spell of night duty. Drawing by Phiz (Hablot K Browne), reproduced from Charles Dickens, Martin Chuzzlewit, London, Chapman and Hall, 1844.

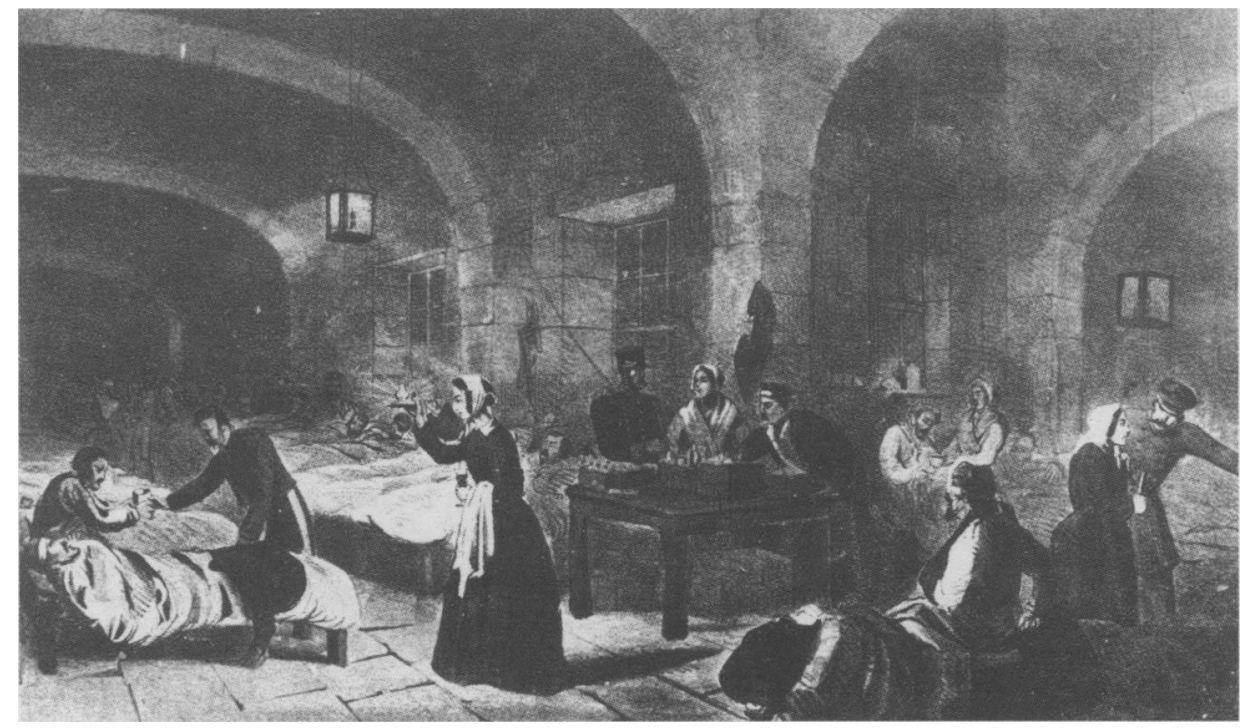

Figure 3: Florence Nightingale in the hospital at Scutari. Lithography by J A Benwell, 1855. Wellcome Library, London. 
Betsey Prig, "a fair specimen of a hospital nurse", had been recommended by St Bartholomew's Hospital as a suitable day nurse. When Mrs Gamp arrived to take over the night duty from her, Betsey Prig advised the use of the patient's pillow to make Sairey's easy-chair more comfortable! $!^{21}$

The work, pay and status of a Betsey Prig were little better than that of a skivvy, the tasks being the endless scrubbing of the ward floors, preparation of food, and elementary, and sometimes unpleasant and dangerous, nursing duties. Her major expertise was the making of poultices. A doctor or medical student would be entrusted with skilled work such as taking the patient's temperature. ${ }^{22}$ The duties of a domestic servant and a nurse were similar and, in some eyes, those of the former were preferable. Elizabeth Davis, "a Balaclava nurse", had had a mixed career before nursing in the Crimea. As well as nursing privately and at Guy's Hospital, she had also been a laundry maid, plain cook, and housemaid, and concluded, "I did not like nursing so well as being in service". She was highly critical of Florence Nightingale as well as some of the nurses, especially "the ill-behaviour of two or three of the party, who disgraced themselves by drunkenness". ${ }^{23}$ This recurring complaint was in part the result of the hospitals providing nurses with a generous ration of beer.

Despite the low social position of nurses, many performed their dangerous duties in a competent and professional manner. Sir James Paget, in an address to the Abernethian Society in 1885, spoke well of some of the sisters and nurses of St Bartholomew's Hospital of fifty years before. "They could not have kept a chart or skilfully taken a temperature, but they had an admirable sagacity, and a sort of rough practical knowledge, which were nearly as good as any acquired skill" ${ }^{24}$

In his preface to the 1849 edition of Martin Chuzzlewit, Dickens expressed his indignation "that the Hospitals with their means and funds, should have left it to private humanity and enterprise, in the year Eighteen Hundred and Forty-nine, to enter on an attempt to improve that class of persons". He appears to have had in mind the Institution of Nursing Sisters, founded in 1840 by Mrs Fry, and other Protestant nursing organizations that closely followed. ${ }^{25}$

Change was certainly resisted by many of the medical profession. As late as 1877 , seventeen years after the founding of the nurses' training school at St Thomas's Hospital, an editorial in the Lancet declared that nurses "possess just enough knowledge to make them dangerous". Its readers were advised to "lock away beyond their reach every particle of medicine, whether poisonous or not ... It is doubtless difficult for a young woman of no great mental calibre and few attainments, to feel

\footnotetext{
${ }^{21}$ Charles Dickens, Martin Chuzzlewit (first published 1844), London, Penguin Books, 1986, pp. 374-90, 474-84.

${ }^{22}$ John F South (Senior Surgeon of St Thomas's Hospital), Facts relating to hospital nurses; in reply to the letter of "one who has walked a good many hospitals" printed in 'The Times' of 13th April last: also, observations on training establishments for hospital and private nurses, London, Richardson Bros, 1857, p. 13; Katherine Williams, 'Ideologies of nursing: their
}

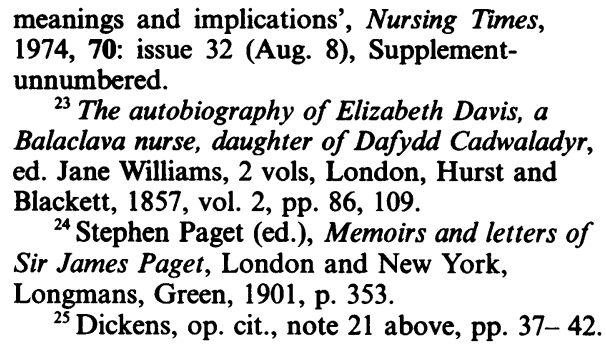

${ }^{25}$ Dickens, op. cit., note 21 above, pp. 37- 42 . 


\section{The Contribution of Elizabeth Fry to Nursing Reform}

herself credited with quasi-medical powers, without becoming possessed with an ambition to use them". ${ }^{26}$

\section{Theodor Fliedner (1800-1864) and the Deaconesses of Kaiserswerth}

In 1824, a young German pastor, Theodor Fliedner, set off for England and Holland to raise funds to assist his poverty-stricken Protestant congregation at Kaiserswerth, near Dusseldorf. In London, he visited Newgate to see the work of Mrs Fry amongst the female prisoners. Inspired by what he saw, on returning to Germany, he set up an association to assist prisoners and, in 1833, he and his wife established a home for female convicts recently discharged from prison. ${ }^{27}$ In 1834 , he again visited London, spending a day with Elizabeth Fry and accompanying her on a second visit to Newgate. Two years later he established a hospital chiefly as a school to train deaconesses to work as nurses in Germany and other countries, including England. ${ }^{28}$

During a visit to Kaiserswerth in 1840 , shortly before she established her own Nursing Institution, Mrs Fry submitted to a thorough inspection the Institution that her "valuable man" and "dear friend" Pastor Fliedner and his wife had founded. The Fliedners had succeeded in creating "so careful a line to be drawn between the extreme sacrifice of freedom of the cloister and the avoidance of a demoralising liberty". ${ }^{29}$

\section{The Institution of Nursing Sisters}

When she was eighteen, Elizabeth Fry recorded in her journal that she visited both the local "Bedlam" and the hospital where "her heart felt much for a poor man who, having undergone a dreadful operation, was reading his prayer book and did not expect to live". ${ }^{30}$ Later, whenever she inspected a prison, she would commonly also visit the local hospital, asylum and workhouse. In 1827 she wrote: "During the last ten years much attention has been successfully bestowed by women on the female inmates of our prisons ... But a similar care is evidently required for our hospitals, our lunatic asylums, and our workhouses". ${ }^{31}$ She may well have had in mind the establishment of "Lady Visitors" to these institutions (as she had done in the prisons) rather than a direct upgrading of the staff through selection and training.

Occupied by her prison work and other charitable activities and coping with health and domestic problems, Mrs Fry took no action to establish her Institution of

\footnotetext{
${ }^{26}$ Editorial, 'Skilled nursing', Lancet, 1877, i: 62.

${ }^{27}$ Catherine Winkworth (transl.), Life of Pastor Fliedner of Kaiserswerth, London, Longmans, Green, 1867, p. 54.

${ }^{28}$ Fry and Cresswell, op. cit., note 4 above, vol. 2, p. 358; Fliedner, op. cit., note 27 above, pp. $100,106-7$.
}

\footnotetext{
${ }^{29}$ Fry and Cresswell, op. cit., note 4 above, vol. 2, pp. 359, 360; Nutting and Dock, op. cit., note 15 above, vol. 2 , p. 20.

${ }^{30}$ Fry, Journals, 11 July 1798, 26 Feb. and 7 Apr. 1799

${ }^{31}$ Elizabeth Fry, Observations on the visiting, superintendence, and government of female prisoners, London, John and Arthur Arch; and Norwich, Hatchard, and S Wilkin, 1827, pp. 4-8.
} 


\section{R G Huntsman, Mary Bruin and Deborah Holttum}

Nursing Sisters until after her visit to Kaiserswerth in 1840. Even then, having accepted the presidency, she handed over the day-to-day work to her sister-in-law and daughters. "She had a vision of a Protestant nursing sisterhood; but her mental and bodily powers yielding together, much that was working in her mind faded away". ${ }^{33}$ Supported by enthusiasts, by the end of the year an organization called "The Protestant Sisters of Charity" was established. This name, used earlier by Mrs Fry's niece to describe the Deaconesses of Kaiserswerth, was objected to by both the Anglican Church and Queen Adelaide. As a result, the name was quickly changed to "The Institution of Nursing Sisters", and the Queen Dowager, who light-heartedly offered to act as an extra nurse if they were short handed, became the Patroness. ${ }^{34}$

The Institution was founded to provide "experienced, conscientious, and Christian Nurses for the sick-and also to raise the standard of this useful and important occupation, so as to engage the attention and enlist the services of many who may be desirous of devoting their time to the glory of God, and to the mitigation of human suffering." The immediate objective of the Institution was to nurse and visit the sick and to comfort the afflicted: "It is the spirit of the Institution of Nursing Sisters that the poor should be attended in their houses with the same kindness and care bestowed upon the more wealthy part of the community". ${ }^{35}$ Despite the religious tone of their "mission statement" and the insistence that all applicants must be Protestant, possess a Bible and attend the services of their particular denomination, the Institution was essentially secular, the nurses, like the Catholic Beguines in the Low Countries, taking no vows. This was not always understood. It was reported that "[i]n Guy's Hospital London, the Quakers had provided nurses who were to work in the spirit of Sisters of Charity, under rules" ${ }^{36}$

The length of contracted service, which followed a short period of hospital training, varied between three and seven years, three years being the most usual. By imposing a lengthy period of contracted service, it was hoped that the problem of nurses leaving immediately after being trained would be overcome. In practice, it was only partly solved and the departure of nurses without consent before the termination of the contract remained a recurring difficulty. If this occurred, the offender would never be re-admitted. ${ }^{37}$ A fine, usually of $£ 3$, was imposed if a nurse left without good reason or was dismissed before her contract ended. Exceptions were made, the forfeit not being imposed on Sister Parkes, who had to leave for America for pressing

\footnotetext{
${ }^{32}$ Report of the first anniversary meeting of the Protestant Sisters of Charity, 3 July 1841, held at 1 Raven Row, SA/QNI/W.1/2; Fry and Cresswell, op. cit., note 4 above, vol. 2, p. 373.

${ }^{33}$ Attributed to Mary Stanley, Hospitals and sisterhoods, 2nd ed., London, John Murray, 1855, p. 37.

${ }^{34}$ Elizabeth Gurney, Elizabeth Fry's journeys on the continent, 1840-1841, ed. R Brimley Johnson, London, John Lane, The Bodley Head, 1931, p. 100; Minutes of the Ladies' Committee, Institution of Nursing Sisters, SA/QNI/W.2/1, 9 July 1841 .
}

\footnotetext{
${ }^{35}$ Report of the Institution for Nursing Sisters, No. 16, Broad Street Buildings, Bishopsgate: established 1840, London, H Teape, 1848, p. 4; Bye-laws of the Institution of Nursing Sisters, undated, SA/QNI/W.1/5.

${ }^{36}$ The Catholic encyclopedia, 15 vols, New York, Robert Appleton, 1907, vol. 2, pp. 389-90; Cameron, op. cit., note 17 above, p. 30.

${ }^{37}$ Rules and Regulations to be observed by the Nursing Sisters, SA/QNI/W.1/4; Minutes of the Ladies' Committee, SA/QNI/W.2/1, 9 Sept. 1842; SA/QNI/W.2/3, 8 Dec. 1848.
} 


\section{The Contribution of Elizabeth Fry to Nursing Reform}

family reasons. ${ }^{38}$ Mrs Reynolds was less fortunate, her appeal to have the deduction of $£ 5$ for the cost of her uniform refunded was rejected. "This Committee decides that as she leaves in consequence of her own misconduct that they cannot grant her request". After disputes with the sisters over payment of this forfeit, in 1850 it was agreed that the fine would be given to the poor box..$^{39}$ If the Ladies' Committee were displeased with a sister, they did not renew her contract. When, in February 1857, this occurred with Sister Campbell, it was found she was still living in the Home in July. She was told to leave "on or before Monday next". ${ }^{40}$

Following the establishment of the "Fry Nurses", a number of successful Protestant sisterhoods were founded, some devoting themselves to hospital nursing. At least one such Institution, "Establissement des Soeurs de Charité Protestantes", founded in Paris in 1841, was acknowledged as being directly inspired by Elizabeth Fry. ${ }^{41}$ Influenced by the Oxford movement, some of the new English sisterhoods "developed extremely high church tendencies" and had "many enemies". Indeed, the very formation of a group of uniformed women living in a home run by women was, at that time in England, enough to arouse public suspicion as an imitation of "Romanism". ${ }^{42}$ Helped by its Quaker roots, the Institution of Nursing Sisters had quietly succeeded in being accepted and, by renouncing "Sisters of Charity" in the original title, had enhanced its Protestant credentials.

\section{Organization and Financial Structure}

Elizabeth Fry's nursing institution benefited greatly from the three years' experience of Pastor Fliedner and his wife at Kaiserswerth. The Institution was run by a Ladies' Committee, which met fortnightly, absentee members being advised that they were expected occasionally to be present. In fact, attendance was usually good, although at an August meeting in 1857, when only two members appeared, a quorum was not attained. In 1857, it was decided that the nurses would be allowed to meet the Committee after the meetings. ${ }^{43}$

Four sub-committees were formed. The first was for "Engaging Sisters", the second for "Guys Hospital", the third for "Raven Row [the Home of the Sisters] and the London Hospital", and the fourth to oversee the "Dress of Sisters". ${ }^{44}$ A Gentlemen's Committee was also set up, which, it was emphasized, would meet occasionally to give assistance "only when called upon by the Ladies Committee". In practice, men only became involved in property transactions and as trustees of the Superannuation

\footnotetext{
${ }^{38}$ Rules and Regulations, SA/QNI/W.1/4; Rules for Trained Nurses, SA/QNI/W.1/6; Minutes of the Ladies' Committee, SA/QNI/W.2/4, 29 Jan. 1858.

${ }^{39}$ Minutes of the Ladies' Committee SA/QNI/ W.2/4, 5 May 1854, 22 June 1855.

${ }^{40}$ Ibid., SA/QNI/W.2/4, 27 Feb. and 10 July 1857.

${ }^{41}$ Ludlow, op. cit., note 14 above, p. 284; Fry and Cresswell, op. cit., note 4 above, vol. 2 , pp. $465-8$.
}

\footnotetext{
${ }^{42}$ Nutting and Dock, op. cit., note 15 above, vol. 2, p. 78; Ludlow, op. cit., note 14 above, pp. 284-90. H P Liddon, Life of Edward Bouverie Pusey, ed. J O Johnston and R J Wilson, 4 vols, London, Longmans, Green, 1894-1898, vol. 3, pp. 26-7.

${ }^{43}$ Minutes of the Ladies' Committee, SA/QNI/ W.2/1, 12 Feb. 1841, SA/QNI/W.2/4, 21 Aug. and 15 May 1857.

${ }^{44}$ Ibid., SA/QNI/W.2/1, 12 Feb. 1841.
} 


\section{$R$ G Huntsman, Mary Bruin and Deborah Holttum}

fund. ${ }^{45}$ One of the trustees was Sir Robert Inglis, a prominent and colourful Member of Parliament for thirty years, whose wife later became President of the Institution. Mr South, senior surgeon at St Thomas's Hospital, made a point of noting the unusual situation that the ladies managed the Institution without male assistance. ${ }^{46}$ Although the ladies did not personally walk the corridors of power, their close proximity to those who did made them a formidable force when dealing with hospital matrons or governors.

Mrs Fry remained president until her death in 1845, although, apart from the first meeting and that of the first anniversary, at which all available sisters were present, she seldom attended meetings, continuing to be assisted in her duties by her sisterin-law Mrs Samuel Gurney, her daughters and other ladies. ${ }^{47}$ After 1845, Lady Inglis, who was clearly keenly interested in the work of the Institution, having regularly attended the committee meetings from 1842 , became the president. ${ }^{48}$

From its inception, the Institution was established to be financially self-supporting, although charitable contributions were sought. ${ }^{49}$ In view of her known interest in hospitals, Elizabeth Fry's decision to establish a nursing institution which did not care for the poor either at home or in hospital, but primarily trained nurses to undertake private work in the homes of wealthy clients, deserves explanation. Private nursing was the only source of income to cover their expenses. It is clear from the addresses of employers that, certainly at the start, and despite the philanthropic nature of their "mission statement", virtually all the nurses were involved in caring for wealthy and often titled families. The Patroness, the Dowager Queen Adelaide, was nursed by a sister from the Institution, Harriet Rowe. ${ }^{50}$ With the passage of time, the Institution became financially viable; this was demonstrated in 1848 by the placing of a brass plate on the door. In 1849, an advertisement appeared in The Times announcing that "The Institution of 'Nursing Sisters' established by Mrs Fry in 1840 under the patronage of the Queen Dowager, continues to send out efficient nurses to all parts of the Kingdom". ${ }^{51}$

By 1847 , there were twenty-six sisters, who produced a yearly income of between $£ 900$ and $£ 1,000$. By 1849 , the Institution had a positive bank balance of $£ 1,12914 \mathrm{~s}$. 1d., with $£ 312$ 9s. 10d. in the superannuation fund for retired sisters. ${ }^{52}$ By $1855 / 56$, the annual income had reached $£ 3,87112 \mathrm{~s}$. $6 \mathrm{~d}$., with a bank balance of $£ 1,1518 \mathrm{~s}$. 2d. A total of $£ 1,76912 \mathrm{~s}$. $6 \mathrm{~d}$. was paid that year to the sisters, who numbered

${ }^{45}$ Ibid., SA/QNI/W.2/1, 26 Feb. 1841; SA/QNI/W.2/3, 13 Nov. 1846, 21 Dec. 1849.

${ }^{46} \mathrm{Ibid} ., \mathrm{SA} / \mathrm{QNI} / \mathrm{W} .2 / 4,9$ Dec. 1853; South, op. cit., note 22 above, p. 25.

${ }^{47}$ Minutes of the Ladies' Committee, SA/ QNI/W.2/1, 12 Feb. 1841; Report of the first anniversary meeting, SA/QNI/W.1/2; Fry and Cresswell, op. cit., note 4 above, vol. 2 , p. 373 .

${ }^{48}$ Minutes of the Ladies' Committee, SA/QNI/ W.2/1, 24 Dec. 1841; SA/QNI/W.2/2, 21 Nov. 1845.

\footnotetext{
${ }^{49}$ Protestant Sisters of Charity. The Treasurer's Book, 1840, SA/QNI/W.3, pp. 2, 6, 16; Report of the Institution for Nursing Sisters, op. cit., note 35 above, p. 4.

${ }^{\text {so }}$ Register of nurses, 1840-1855, SA/QNI/W.4 (OS 83); Register of occupation in nursing the sick, 1840-1845, SA/QNI/W.5; Correspondence, 4 Oct. 1849, SA/QNI/W.6/1.

${ }^{51}$ Minutes of the Ladies' Committee, SA/QNI/ W.2/3, 11 Feb. 1848; 22 June 1849.

${ }^{52}$ Fry and Cresswell, op. cit., note 4 above, vol. 2, p. 374; minutes of the Ladies' Committee, SA/QNI/W.2/3, 28 Sept. 1849.
} 


\section{The Contribution of Elizabeth Fry to Nursing Reform}

approximately ninety. ${ }^{53}$ They thus each received an annual salary of about $£ 20$, with full board and their uniform provided. This fits well with figures of "about twenty guineas" and $£ 20$ rising to $£ 23$ after three years, given by biographers. ${ }^{54}$ Somewhat later, in 1869, a nurse at Guy's Hospital received between $£ 26$ to $£ 30$ per annum, the cost of supplying beer from the hospital brewery for each nurse being $£ 2$ per annum. At Guy's, "the salaries of the nurses and other servants were fixed at a considerably higher rate than in any other hospital, the better to prevent them from extorting money from the patients". ${ }^{55}$ In 1861, 2.7 million women and girls over the age of fifteen in England and Wales, 26 per cent of the total female population at that time, were gainfully employed, nearly half of them in domestic service. ${ }^{56}$ The few records of previous occupation in the minutes of the Institution suggest that it was from this vast pool of workers that many of their nurses were recruited. ${ }^{57}$ In order to attract such women, the salary offered by the Institution had to compare favourably with the wages and conditions being offered for a comparable and competitive position in domestic service. At that time, a head nurse living in a private household would be paid between $£ 13$ and $£ 30$ per annum, depending on whether she received an allowance for tea, sugar and beer. A nurse maid, dependent on the same conditions, would earn between $£ 5$ and $£ 12 .{ }^{58}$

In 1851, the Ladies' Committee had decided that a fair charge to their patrons for an experienced nurse was $£ 1$ a week. This appears to have comfortably covered their expenses. Apprehensions about the institution's financial stability must by then have been greatly diminished. The increasing funds at the Committee's disposal in 1853 allowed the ladies to raise the superintendent's salary by $£ 10$ per annum, the total paid not being disclosed. However, Mrs Kennion, the first superintendent, who was reprimanded for secretly marrying, was described as "passing rich on $£ 40$ a year" ${ }^{59}$ Although private nursing remained the major occupation, charitable work, which was unprofitable for the organization, slowly built up from about that time. ${ }^{60}$

Financial control remained tight, as can be seen by the reduction of expenditure on the sisters' uniforms, which in $1855 / 6$ cost $£ 19011$ s. 8d. per annum. The expensive, intricately patterned silk or fine worsted Norwich shawl, clearly favoured by their Norfolk born founder, and previously worn by the sisters, was replaced by a woollen

${ }^{53}$ South, op. cit., note 22 above, p. 28 ; Nutting and Dock, op. cit., note 15 above, vol. 2, p. 76.

${ }^{54}$ Fry and Cresswell, op. cit., note 4 above, vol. 2, p. 374; E R Pitman, Elizabeth Fry, Eminent Women Series, new ed., London, W H Allen, 1889, p. 175.

${ }_{55} \mathrm{~J}$ C Steele, 'Statistical account of the patients treated in Guy's Hospital during 1869', Guy's Hospital Reports, Series 3, 1870-71, 16: 540-1; Samuel Wilks and G T Bettany, A biographical history of Guy's Hospital, London and New York, Ward, Lock, Bowden, 1892, p. 80.

${ }_{56} \mathrm{~J}$ Burnett (ed.), Useful toil: autobiographies of working people from the 1820s to the 1920s, London and New York, Routledge, 1994, p. 7.

\footnotetext{
${ }^{57}$ Minutes of the Ladies' Committee, SA/QNI/ W.2/3, 31 June 1850; 22 Oct. 1847.

${ }^{58}$ Isabella Beeton, The book of household management, London, S O Beeton, 1861, p. 8; Samuel and Sarah Adams, The complete servant, London, Knight and Lacey, 1825, pp. 5-6.

${ }^{59}$ Minutes of the Ladies' Committee, SA/QNI/ W.2/3, 19 Dec. 1851, 15 Mar. 1853; Sarah A Tooley, The history of nursing in the British empire, London, S H Bousfield, 1906, pp. 33-4.

${ }^{60}$ Minutes of the Ladies' Committee, SA/QNI/ W.2/3, 26 Oct. 1849.
} 


\section{$R$ G Huntsman, Mary Bruin and Deborah Holttum}

shawl. ${ }^{61}$ Sister Leitz took advantage of her privilege to appear, presumably wearing her uniform, before the Committee to complain that her dress was much worn and a replacement was overdue. The Committee decided to write to Miss Ollivier, the lady in charge of the "Dress of Sisters" sub-committee. The Ladies' Committee demanded value for money and complaints were made when the work at the laundry at the Institute for the Destitute was unsatisfactory. ${ }^{62}$

Most of the minutes of the Ladies' Committee meetings dealt with the intricate details of staff selection and discipline, which in a modern organization would be the responsibility of senior management, in their case the superintendent. This personal involvement is understandable as the major challenge facing the Institution was to upgrade the calibre of the nurse employed. To achieve this, the Committee sought a moral uplift rather than an alteration in the social status of the nurses recruited. In her biography, Janet Whitney wrote, "Mrs. Fry was as far as Mrs. Nightingale from considering nursing as a possible profession for her own daughters. The Fry Nurses were respectable women of what was in those days called the lower class". ${ }^{63}$

The ladies of the Committee with their retinue of domestic servants would be familiar with this class of person, and controlling them, albeit often indirectly through the housekeeper and butler, was an area in which they could operate with the greatest comfort. It was advised that, for example, a family with, by their standards, a modest income of $£ 4,000$ to $£ 5,000$ per annum, should have eleven female and thirteen male servants. Such servants were required to care for not only the family but also the numerous guests that were a feature of country house living at that time. On 14 August 1812, in addition to her own large family, Mrs Fry reported having eighteen guests staying in her house. Her servants would not have been included in the count. $^{64}$

The resulting extraordinary attention to detail found in the minutes has bequeathed a unique document. It presents an efficient, female controlled health care organization run by "part-time amateurs" and functioning from the early years of Queen Victoria's reign until 1939. Despite every care in selecting candidates, they did not find their managerial tasks easy, as the many subsequent dismissals of their staff for misconduct demonstrate. The control by the ladies of the superintendent and nurses was based on social superiority and resembled the relationship they would have enjoyed at home with their housekeeper and domestic staff. For example, a sister who wished to nurse in Madeira was refused permission as "it would be injurious to the Sisters if they were removed beyond the supervision of the home". ${ }^{65}$

Between 1842 and 1860 the Institution of Nursing Sisters was based at Devonshire Square, and in contemporary records the sisters were commonly called "Devonshire Square" Nursing Sisters or "Fry Nurses". The number of nurses peaked at a hundred

\footnotetext{
${ }^{61}$ South, op. cit., note 22 , above, p. 28 ; minutes of the Ladies' Committee, SA/QNI/W.2/ 4, 15 Dec. 1854.

${ }^{62}$ Minutes of the Ladies' Committee, SA/QNI/ W.2/3, 19 Nov. 1847, SA/QNI/W.2/1, 26 Aug. 1842.
}

\footnotetext{
${ }^{63}$ Janet Whitney, Elizabeth Fry, Quaker heroine, London, George G Harrap, 1937, p. 298.

${ }^{64}$ Fry and Cresswell, op. cit., note 4 above, vol. 1, p. 191.

${ }^{65}$ Minutes of the Ladies' Committee, SA/QNI/ W.2/3, 4 Aug. 1848 .
} 


\section{The Contribution of Elizabeth Fry to Nursing Reform}

but, after 1913, fell to sixty due to competition from private agencies. During and after the 1914-18 war, the number decreased further and the Institution was described as "continuing its quiet course" at its final home in 10 Collingham Road, South Kensington. ${ }^{66}$ The minutes of the final meeting on 7 December 1939 record that the Committee had planned a pink meeting card for 1940 but that the time of the meeting had been omitted as, because of the war, it might have to be changed. ${ }^{67}$ There are no minutes for the next meeting, fixed for 4 January 1940 . No indication is given in those last minutes of a projected closure, and local enquiry produced no history of bomb damage to the home, which might account for this sudden end. Indeed, the building was subsequently occupied by the British Red Cross. ${ }^{68}$ One assumes that with a diminishing number of nursing staff the organization ran into problems similar to those experienced in the First World War. The financial assets and lease were given to the Queen's Nursing Institute in $1945 .^{69}$

\section{Nursing Staff Selection}

All applicants had to be physically fit, neither too large nor too short. A candidate of twenty-three was considered too young. Another, also thought too young, was more suited to be an invalid lady's attendant. A further candidate aged forty-eight, was considered too old. ${ }^{70}$ Excellent references were demanded, and then checked, and all applicants were interviewed. In one case, a candidate recommended by Miss Fry was rejected after further enquiries were made by the Committee. ${ }^{71}$ Ten years after the Institution was set up, it was still found necessary to ascertain, during the interview, that the candidates did not fear hospitals or object to wearing the uniform. ${ }^{72}$ Despite recommendations and references, a number were rejected at interview, one being refused because of her abrupt and unpleasant manner, and another, the widow of a sergeant, was "not particularly suitable". ${ }^{73}$ Those who could not read and write were not admitted. Despite every care in screening, it was found that one probationer, who was by then already training at Guy's Hospital, could not read properly. It was decided that she would be instructed by the superintendent. ${ }^{74}$

Often no information is recorded on the single women who applied, unless they already had nursing experience. But the previous employment of some of the candidates is noted. Among them were a housemaid, a private nurse, a family cook, a turnkey at Abingdon Jail, and a single woman who kept house for her father, as well as the daughters of a Baptist minister, a draper and a tailor. The daughter of

\footnotetext{
${ }^{66}$ Anon., A short history of the Institution of Nursing Sisters, London, J B Shears, c. 1934, SA/ QNI/W.8.

${ }^{67}$ Minutes of the Ladies' Committee, SA/QNI/ W.2/13, 7 Dec. 1939.

${ }^{68}$ Personal Communication, Royal Borough of Kensington and Chelsea, Chelsea Library, Local Studies Department.

${ }^{69}$ Introduction to 'The Queen's Nursing Institute, list of papers in the Contemporary Medical Archives at the Wellcome Institute for the History of Medicine'
}

(SA/QNI), compiled by Shirley Dixon (unpublished), p. 98.

${ }^{70}$ Minutes of the Ladies' Committee, SA/QNI/ W.2/3, 30 July 1847, 2 Feb. and 9 Nov. 1849, 23 June 1848. 1846.

${ }^{71}$ Ibid., SA/QNI/W.2/3, 24 Nov. 1848, 28 Feb.

${ }^{72}$ Ibid., SA/QNI/W.2/3, 28 Mar. 1850.

${ }^{73}$ Ibid., SA/QNI/W.2/3, 2 July 1847, 22 Dec. 1848.

${ }^{74}$ Ibid. SA/QNI/W.2/4, 20 Jan. 1854, SA/QNI/ W.2/3, 4 Aug. 1848. 


\section{$R$ G Huntsman, Mary Bruin and Deborah Holttum}

the tailor had previously nursed at St Bartholomew's Hospital, and another candidate at that meeting had nursed at Guy's Hospital for five years. ${ }^{75}$

By contrast, in the case of widows, the occupation of the husband, usually an artisan or tradesman such as a printer or cabinet maker, was commonly given. It was particularly noted that the ex-husband of one candidate was not a common porter but a lodge porter at Somerset House. ${ }^{76}$ Occupations other than tradesmen such as apothecary, medical assistant or Master in the Merchant Service also occur, albeit uncommonly. ${ }^{77}$ Married women were not acceptable if the husband was still living. One, rejected for this reason, was described as elderly and without nursing experience, suggesting a more liberal attitude might have been adopted in more favourable circumstances. The wife of a surgeon, who was now a lunatic, was rejected, but, curiously, an exception was made in the case of the woman still married to a jeweller who was insane. ${ }^{78}$

On marriage, the serving sister had to present her certificate attested by the clergyman of the parish to the Ladies' Committee to receive her testimonials. She would normally resign and forfeit her pension, the Ladies' Committee retaining discretion over implementing the ruling. One nursing sister who had left to get married found she had been deceived by her suitor. The Ladies' Committee were prepared to reconsider her case and to make further enquiries. ${ }^{79}$

The applications of the sub-matron of the Magdalen Asylum in Birmingham and the matron of the Paddington Workhouse and Laundry in the Refuge for the Destitute $^{80}$ suggest that some women were prepared to accept an apparent demotion in rank to be employed by the Institution. The committee rejected an application by Dr Sieveking, physician to the Prince and Princess of Wales, for women from the workhouses to be accepted as nurses. Florence Nightingale also expressed concerns about the necessary training required for such a recruitment strategy. ${ }^{81}$

A few years after the Institution's foundation, the background of the successful candidate slowly changed. From the beginning, the organization had encountered difficulties in finding hospitals willing to train their nurses. A candidate with previous hospital experience was seen as desirable as she required no training and could commence nursing immediately. This saved the Institution time and money and, by removing the hospital training bottle-neck, allowed a more rapid increase in the number of nurses employed.

In addition, from about 1845 , the Committee specifically began to seek nurses prepared to visit the sick poor. One, Mrs Moody, had no objection to such cases. Another said she had been accustomed to visit the poor for the Strangers' Friend Society. This Society, which became a mainly Wesleyan organization, was founded towards the end of the eighteenth century and was one of the first organizations

\footnotetext{
${ }^{75}$ Ibid., SA/QNI/W.2/3, 31 June 1850, 4 Aug. 1848, 22 Oct. 1847, 13 Sept. 1850, 28 Jan. and 11 Feb. 1848, 5 Feb. 1847.

${ }^{76}$ Ibid., SA/QNI/W.2/3, 4 Sept. 1846, 16 Feb. 1849, 22 Jan. 1847.

${ }^{77}$ Ibid., SA/QNI/W.2/3, 23 July 1852, 28 Mar. 1850, 5 Nov. 1847 .
}

\footnotetext{
${ }^{78}$ Ibid., SA/QNI/W.2/3, 2 Feb. and 13 Apr. 1849, 8 Oct. 1847.

${ }^{79}$ Ibid., SA/QNI/W.2/4, 16 Jan. 1857; SA/QNI/ W.2/3, 9 July 1852 .

${ }^{80}$ Ibid., SAVNI/W.2/3, 18 June and 9 Apr. 1847.

${ }^{81}$ Ibid, SA/QNI/W.2/3, 24 Nov. 1848; Bunsen, op. cit., note 10 above vol. 2, pp. 22-3.
} 
devoted to parochial visiting. ${ }^{82}$ In 1850 , Mrs Jay, another candidate, was thought capable of sick poor nursing, whereas Mary Nagle, "whose heart would not be in nursing the poor" was offered only a supernumerary position, to work if required. ${ }^{83}$ The Ladies' Committee appeared to recognize that special qualities and experience were needed in this area. In 1850, Frances Turner was specifically taken on probation to attend the poor, and to assist with the needlework, but she was later found not to have sufficient experience. A year later, a nurse, Ann Harvey, was, unusually, appointed on trial specifically to nurse the sick poor. ${ }^{84}$

\section{Hospital Training}

For the first two years, until it moved to a more central location, ${ }^{85}$ the Mother House of the Institution was at 1, Raven Row (now demolished), immediately adjacent to the London Hospital, which had been selected to train the nurses. The nursing historian, Sarah Tooley, who visited it some time before 1906, described this "historic site" as "a squalid little turning by the Eastern Post Office, Whitechapel, and one imagines it was not very salubrious in 1840". A broken window had a dirty card in it bearing a scrawl, "Here lives a good nurse" surmounted by Hebrew characters. $^{86}$

The influence of the Quaker movement at the London Hospital was probably why it was chosen. The recognizable Quaker names of Fry, Gurney, Barclay, Hanbury, Hoare and Buxton are regularly found in the minutes of the House Committee's or Governors' meetings of the hospital at that time.$^{87}$ The first probationer, Jane Wade, began her three months' training at the London Hospital on 26 August 1840, and completed it on 23 October. After only three nurses had been received at the London Hospital, both the probationer and a nurse were withdrawn because of "the uncleanly state of the establishment" ${ }^{88}$

In September 1841, Guy's Hospital agreed to take two trainee sisters, but at the end of the year the Institution had to request a renewal of their permission. When, in 1844, Guy's Hospital decided to take only one trainee at a time, Lady Inglis wrote asking that two nurses should continue to attend. At the same time the Institution made enquiries at King's College Hospital, and St George's Hospital was also approached as to "the nature of the duties required for our sisters to be instructed in". A probationer subsequently completed her training in the latter. ${ }^{89}$

If there was a problem, the President of the Institution, or the sub-committee responsible for that hospital, would not hesitate to visit. The Matrons of Guy's,

\footnotetext{
${ }^{82}$ Minutes of the Ladies' Committee, SA/QNI/ W.2/2, 7 Mar. 1845; SA/QNI/W.2/3,

10 Nov. 1848; Ludlow, op. cit., note 14 above, p. 200.

${ }^{83}$ Minutes of the Ladies' Committee, SA/QNI/ W.2/3, 18 Jan. and 22 Nov. 1850.

${ }^{84}$ Ibid., SA/QNI/W.2/3, 21 Apr. and 10 May 1850, 31 Jan. 1851.

${ }^{85}$ Ibid., SA/QNI/W.2/1, 11 Mar. 1842. p. 32 .
}

\footnotetext{
${ }^{87}$ Minutes of the House Committee, General Committee Report Book, to be presented to the Quarterly General Court, and General Court Minute Book, all at the London Hospital Archives, London Hospital.

${ }^{88}$ Register of Nurses, 1840-1855, SA/QNI/ W.4; minutes of the Ladies' Committee, SA/QNI/ W.2/1, 15 and 29 July, and 26 Aug. 1842.

${ }^{89}$ Minutes of the Ladies' Committee SA/QNI/ W.2/1, 3 Sept. 1841; SA/QNI/W.2/2, 23 Feb., 22 Mar. and 3 May 1844.
} 
King's College and the Westminster Hospitals were called on to discuss nurses, and in 1850 , following a visit by Lady Inglis, it was arranged that the sub-committee responsible for Guy's Hospital would meet the probationers. ${ }^{90}$ It is probable that assessment of a hospital would focus on, but not be confined to, general cleanliness, the nurses' working conditions and the training they received. In 1852, due to structural alterations at Guy's Hospital, it became necessary to send the probationers from the Institution to St Thomas's. The Ladies' Committee insisted the nurses must continue to live in the Home. Despite the much greater expense, they decided "to continue the arrangement for the present, the instruction seeming to be very good". ${ }^{91}$

The Ladies' Committee were adamant that they must receive satisfactory testimonials for each of their probationers from the hospital responsible for their training. The conduct of one, Caroline Smith, at Guy's Hospital was so bad she was dismissed.$^{92}$ After they received a report from St Thomas's that a probationer showed "capabilities as a surgical nurse", it was thought necessary to ask Mr Whitfield, the apothecary, who was subsequently responsible for instructing the Nightingale nurses, to ensure that the training was not confined to the surgical wards. ${ }^{93}$ The apothecary, the keystone of hospital practice, was the only full-time resident member of staff and was viewed as an underprivileged member of the medical profession. ${ }^{94}$ On being told that the trainees were attending St Thomas's for only four hours a day, the Committee informed the probationers that they must in future arrive in the early morning and stay as long as any experience was obtainable. They were later ordered to leave the Mother House by 8 a.m. and return by teatime. If they were to sit up all night, they must have their dinner in an eating house near the hospital. ${ }^{95}$

As early as 1842 , the Committee recognized that a longer training period was needed ${ }^{96}$ but, because it was already proving extremely difficult to arrange only three months' hospital training, it was a considerable time before it could be increased. Eventually, by the turn of the century, the training period reached three years until, finally, only trained nurses were accepted, who were then given three months' probation by the Institution. The newly received sister continued to appear before the Ladies' Committee where she was read an Address, a kind of charge, which had been printed in 1848, "which doubtless surprises the young modern nurse by its solemnity". 97

The somewhat casual nature of the training arrangement, which, in the early days, made the knowledge imparted to the trainee dependent on the goodwill of a potentially resentful hospital nurse or sister with no formal obligation or financial reward for teaching, would be recognized by the Committee as a problem. The

\footnotetext{
${ }^{90}$ Ibid., SA/QNI/W.2/3, 29 May 1846, 7 May 1847, 15 Mar. 1850. 1853.

${ }^{91}$ Ibid., SA/QNI/W.2/3, 24 Dec. 1852, 1 Apr.

${ }_{92}$ Ibid., SA/QNI/W.2/3, 25 Oct. 1850; SA/ QNI/W.2/4, 6 Jan. 1854, 10 July 1857; SA/QNI/ W.2/3, 15 Mar. 1850.

${ }^{93}$ Ibid., SA/QNI/W.2/3, 11 Nov. 1853.

${ }^{94} \mathrm{John}$ Woodward, To do the sick no harm: a study of the British voluntary hospital system to
}

1875, London and Boston, Routledge \& Kegan Paul, 1974, p. 28.

${ }^{95}$ Minutes of the Ladies' Committee, SA/QNI/W.2/4, 26 Sept. and 24 Oct. 1856, 23 Apr. 1858.

${ }^{96}$ Ibid., SA/QNI/W.2/1, 1 July 1842.

${ }^{97}$ Ibid., SA/QNI/W.2/3, 24 Nov. 1848; A short history, op. cit., note 66 above, p. 5; Tooley, op. cit., note 59 above, p. 40 . 


\section{The Contribution of Elizabeth Fry to Nursing Reform}

senior surgeon of St Thomas's Hospital reported very favourably on the probationers from the Institution, describing them as "attentive and observant, quiet and obliging, at all times ready to afford any assistance or service desired of them, and on the best possible terms with the sisters of the wards". ${ }^{98}$ Sarah Tooley, reported in 1906, perhaps more realistically: "I have heard the training of these early days described 'as much cleaning, scrubbing, and polishing, varied by sitting at the bedside or standing in the out-patients' department" "99 If problems arose during hospital training, the probationers were able to approach the Ladies' Committee. When complaints about Guy's were received from Sister Hughes, Mrs Hagen visited the hospital and reported back to the Committee. Problems with the probationers at the London Hospital proved to be intractable and are considered later. ${ }^{100}$

Early on, the Ladies' Committee made special efforts to either train or recruit nurses in selected specialities. In 1841, it was noted that Mrs Cornish had been trained in the care of insane persons, ${ }^{101}$ and, in 1845 , efforts were made to offer the nursing sisters training in that speciality. Nurses "who do not object to mental cases" were sent to Hanwell Lunatic Asylum "for the purpose of becoming better acquainted with the treatment of that malady", ${ }^{102}$ and, from 1847, previous psychiatric experience appeared to be an asset and was regularly noted during recruitment. One such applicant was, in addition, described as a daughter of a shoemaker and another as a single person, Irish. ${ }^{103}$ Arrangements being made in 1841 to send a nurse for training to the Lying-in Hospital in the City Road were cancelled when the hospital informed the Institution that "no gratuitous education is given". ${ }^{104}$ Tooley's statement that hospitals were paid a guinea a week to train the Institution nurses may have applied to a later date. ${ }^{105} \mathrm{~A}$ nursing sister was also successfully sent for orthopaedic training. ${ }^{106}$

It is easy nowadays to criticize the Institution of Nursing Sisters for the short period of training offered. One historian has claimed that their nurses had no training at all. ${ }^{107}$ Whilst another, acknowledging that training had been introduced, dismissed it as "meagre even by 1860 standards". ${ }^{108}$ In 1871, the Nightingale Training School at St Thomas's Hospital was offering one year's training, "at the close of a year their training will usually be considered complete". ${ }^{109}$ Putting aside the fact that a nurse at that time had less skills to learn than her modern equivalent, it must be remembered that the probationers from the Institution of Nursing Sisters were accepted, apparently with some reluctance, by hospitals as a favour. A demand for longer training, which in 1842 the Ladies' Committee thought desirable, would have

\footnotetext{
${ }^{98}$ South, op. cit., note 22 above, p. 26.

${ }^{99}$ Tooley, op. cit., note 59 above, p. 37.

${ }^{100}$ Minutes of the Ladies' Committee, SA/ QNI/W.2/1, 3 June and 15 July 1842.

${ }^{101}$ Ibid., SA/QNI/W.2/1, 12 Mar. 1841.

${ }^{102}$ Ibid., SA/QNI/W.2/2, 9 May 1845.

${ }^{103}$ Ibid., SA/QNI/W.2/3, 5 Mar. 1847, 29 Sept. 1848, 7 Jan. and 2 Sept. 1853. 1842.

${ }^{104}$ Ibid., SA/QNI/W.2/1, 4 and 18 Feb.

${ }^{105}$ Tooley, op. cit., note 59 above, p. 37.
}

\footnotetext{
${ }^{106}$ Minutes of the Ladies' Committee, SA QNI/W.2/2, 26 Sept. 1845.

${ }^{107}$ Gwen Hardy, William Rathbone and the early history of district nursing, Ormskirk, G W and A Hesketh, 1981, p. 4.

${ }^{108}$ Mary Stocks, $A$ hundred years of district nursing, London, George Allen and Unwin, 1960, p. 21.

${ }^{109}$ Roy Wake, The Nightingale Training School 1860-1996, London, Haggerston Press, 1998, Plate 8, Regulations for Training, 1871.
} 


\section{R G Huntsman, Mary Bruin and Deborah Holttum}

increased the hospitals' resistance. In addition, the longer the training, the greater the financial burden that the Institution suffered. The response, as mentioned above, was to view with favour any candidate with previous hospital experience, who therefore did not require training.

At that time, any attempt to offer structured nursing training, however inadequate, to Protestant women in England was revolutionary. Assisted by the experience gleaned from Kaiserswerth, the ladies were treading new ground. The Institution of Nursing Sisters itself taught a lesson to those that followed-that any hospital or institution that required qualified nurses could not rely on the goodwill of another hospital to train them.

\section{Discipline}

Sisters were expected to come provided with a Bible, "considering no person would offer herself as a candidate who had not made such her previous study". Attendance at morning and evening religious services was compulsory. No one was admitted after the service had commenced and those absent would be reported, as was Sister Smith. ${ }^{110}$ Staff were entitled to two weeks' holiday a year, Sister Hudson, who was too inactive and careful of herself, being advised to take a holiday in the hope that she would do better in the future. ${ }^{111}$

As indicated above, the Ladies' Committee viewed their relationship to their staff, despite the mature age of many of the nurses, as that of a caring employer towards his servants or, in some respects, a father to his unmarried daughter. The nursing sisters were to obey the instructions of the ladies of the Committee and show due respect and submission to the superintendent. ${ }^{112}$ The control over them was limited only by the fact that, when employed at private nursing, the sisters resided outside the discipline of the home. They had to travel to and from their work at the least cost, paying for any excess themselves, but this rule was waived for night journeying. Unless they obtained the permission of the superintendent, they slept at their place of work. ${ }^{113}$

The dark brown uniform with the muslin cap modified from the "turban"-like Quaker headdress commonly worn by Elizabeth Fry (see Figure 4) was, from the start, the cause of much discontent among the nurses. ${ }^{114}$ It became necessary to include in the Rules and Regulations a clause ensuring that applicants had no objection to wearing the obligatory nursing sisters' Institution dress in the Home and when on duty. This was reinforced by a specific enquiry at the interview prior to a nurse's appointment. Sister Jacks was dismissed for wearing her own dress at a case, and the minute stating that if a sister wore any dress but that furnished by

\footnotetext{
${ }^{110}$ Rules and Regulations, SA/QNI/W.1/4; minutes of the Ladies' Committee, SA/QNI/W.2/4, 29 Aug. 1856; SA/QNI/W.2/3, 13 Aug. 1847.

${ }^{111}$ Minutes of the Ladies' Committee, SA QNI/W.2/3, 1 Feb. 1850; Register of Nurses, 1840-1855, SA/QNI/W.4; minutes of the Ladies' Committee, SA/QNI/W.2/4, 10 July 1857.
}

\footnotetext{
${ }^{112}$ Rules and Regulations, SA/QNI/W.1/4.

${ }^{113}$ Bye-laws of the Institution of Nursing Sisters, SA/QNI/W.1/5.

${ }^{114}$ Minutes of the Ladies' Committee, SA/ QNI/W.2/4, 25 Apr. 1856; A short history, op. cit., note 66 above pp. 5, 9, 11; minutes of the Ladies' Committee, SA/QNI/W.2/1, 30 Apr. 1841; SA/ QNI/W.2/2, 30 June 1843.
} 


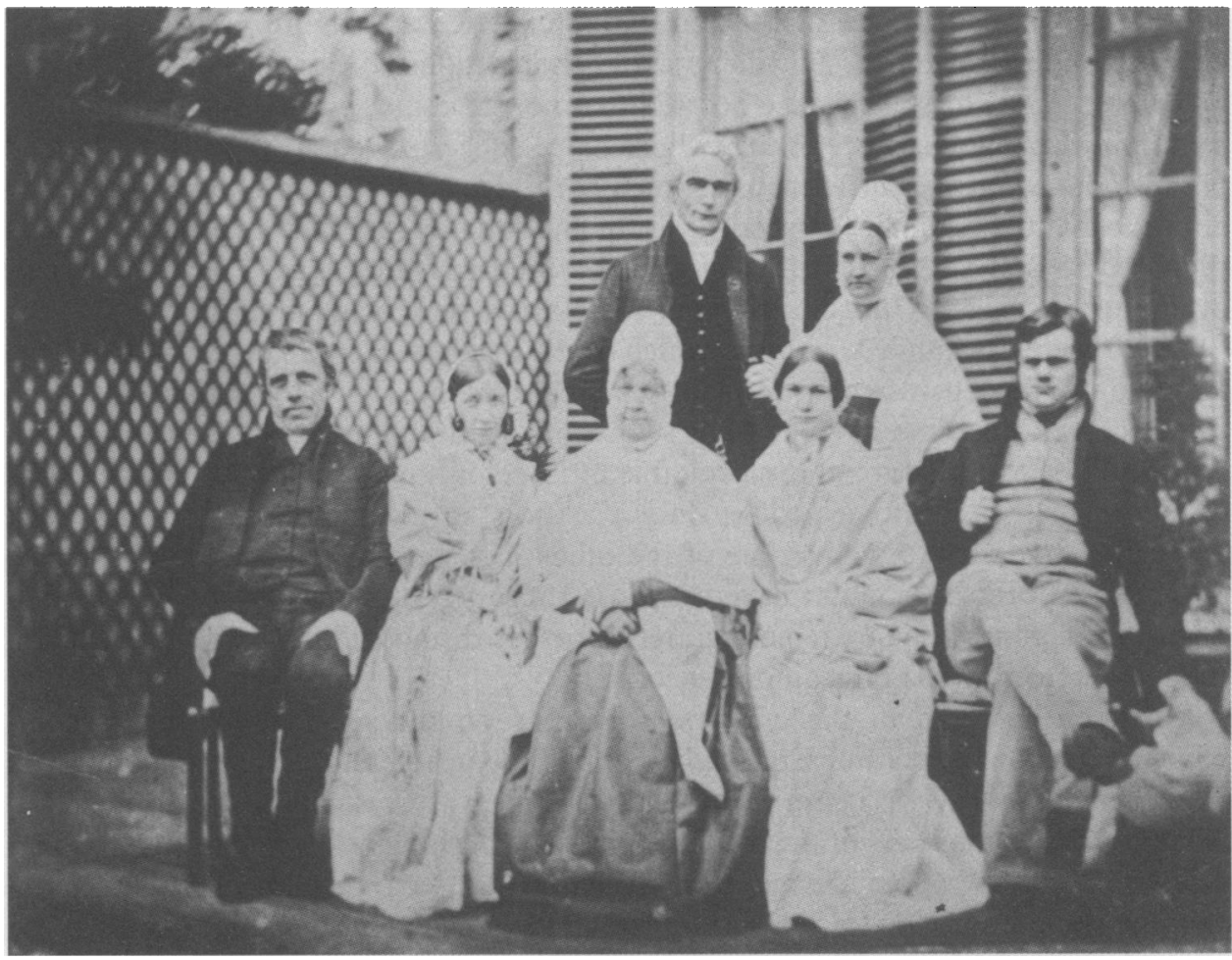

Figure 4: Elizabeth Fry with her relatives, 1842/3. Elizabeth Fry, seated centre, is wearing the Quaker headdress of that period. Her youngest brother, Joseph John Gurney, who travelled to America in 1837, is standing with his third wife. Both Josiah Forster (sitting first from left) and Elizabeth Fry's niece Anna Gurney (sitting fourth from left) accompanied her on her visits to the Continent. Reproduction courtesy of the Library Committee, Religious Society of Friends, London.

the Institution she would receive three months' notice, indicates that the rule was strictly enforced. ${ }^{115}$ Only a dark fur tippet or cuffs were allowed as adornments to the uniform; lace, embroidery and ornaments were specifically forbidden. Sister Godfrey was told not to wear ribbons and, in addition, the wearing of mourning was prohibited. ${ }^{116}$ On leaving, the uniform had to be returned and a letter would be written to any sister who failed to comply. ${ }^{117}$

The Nursing Sisters had their own rights. The brief 1934 history of the Institution states that "No member of the Staff is booked to undertake General Duty in a Private Nursing Home, in a Hospital or on a District unless she is herself quite

${ }^{115}$ Rules and Regulations, SA/QNI/W.1/4; minutes of the Ladies' Committee, SA/QNI/W.2/ 3, 28 Mar. 1850; SA/QNI/W.2/4, 7 May 1858; SA QNI/W.2/3, 5 Nov. 1847.
${ }^{116}$ Minutes of the Ladies' Committee, SA/QNI/ W.2/2, 29 Nov. 1844; SA/QNI/W.2/1, 4 Feb. 1842. 1842 . 


\section{$R$ G Huntsman, Mary Bruin and Deborah Holttum}

willing and is glad of the useful and varied experience it affords". ${ }^{118}$ The Ladies' Committee recognized the unwillingness of many higher calibre applicants to participate in these areas. They also decreed that no nurse should stay longer than three months on any case. ${ }^{119}$ Sister Leitz (whose name suggests she may have been selected because she could speak German) claimed her rights and is recorded as objecting to remaining at the German Hospital. ${ }^{120}$ The policy later introduced of recruiting nurses prepared to undertake district, mental or hospital nursing suggests that the wishes of any of the existing staff not to enter these areas were being honoured.

After each assignment, during which time the nurses must not "talk of the Home", ${ }^{121}$ a report was received from the employer and, if this was unsatisfactory, the sister was interviewed by the Ladies' Committee. Standing before the Committee, she would be expected to adopt a suitable attitude of humility. Sister Clift, who was dismissed for being intoxicated on duty, was not "so penitent as they could wish" during her interview. ${ }^{122}$ That some of the other staff were also not as submissive as the Ladies' Committee might have wished is suggested by the letter received from a sister "professing to be extremely grateful for her dismissal". They also received a rude letter from Mrs Lodge, an ex-sister. ${ }^{123}$

Most, but not all, of the employers' reports on the sisters were highly complimentary. However, Sister Cordingly received a bad reference after attending Mrs Corbett, and a nurse who gave the wrong medicine was warned but not dismissed. ${ }^{124}$ She may have owed her job to the fact that their own founder, when attending her daughter Louisa, "whom she was sedulously nursing, in a moment of agitation and distress, she administered a lotion in mistake for a draught, which was likely to be seriously injurious". ${ }^{125}$

The Ladies' Committee found in favour of Sister Wade, who was accused of being over fastidious about the food supplied by her employer. ${ }^{126}$ Sister Provost, accused of want of cleanliness and idleness, obtained an appointment at the London Hospital before she could be interviewed. She was duly fined $£ 3$, which was donated to the poor box. ${ }^{127}$ When Sister Calvert, who had a bad temper, received an unsatisfactory testimonial, she was advised to leave the Institution and get employment as a hospital sister as soon as possible. She duly resigned. ${ }^{128}$

Discipline was strict, no male visitors were allowed in the Home or at the hospital. At the next meeting it was clarified that this included relatives. No female visitors were allowed meals or permitted to sleep at the Home, although tea might be served

\footnotetext{
${ }^{118}$ A short history, op. cit., note 66 above, p. 11 .

${ }^{119}$ Minutes of the Ladies' Committee, SA/ QNI/W.2/3, 10 May 1850.

${ }^{120}$ Ibid., SA/QNI/W.2/2, 29 Jan. 1846.

${ }^{121}$ Ibid., SA/QNI/W.2/3, 2 Feb. 1849.

${ }^{122}$ Ibid., SA/QNI/W.2/2, 7 Oct. 1843; SA/QNI/ W.2/1, 17 June and 29 July 1842.

${ }^{123}$ Ibid., SA/QNI/W.2/4, 26 June 1857; SA/ QNI/W.2/3, 9 Mar. 1847.
}

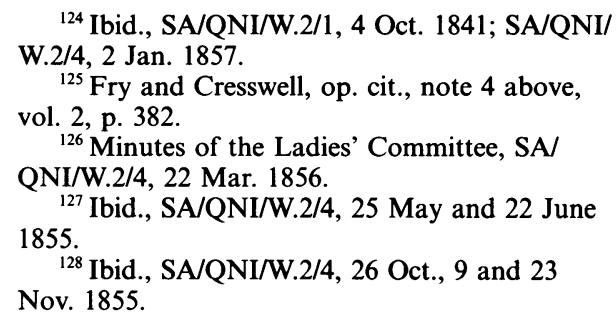

${ }^{124}$ Ibid., SA/QNI/W.2/1, 4 Oct. 1841; SA/QNI/

2/4, 2 Jan. 1857

${ }^{125}$ Fry and Cresswell, op. cit., note 4 above

2 , p. 382 . NI/W.2/4, 22 Mar. 1856 1855 Nov. 1855. 


\section{The Contribution of Elizabeth Fry to Nursing Reform}

to special cases. ${ }^{129}$ No spirits were allowed in the Home, a problem that constantly recurred. "That under no excuse whatever, are spirits to be sent for, or brought into the house, by the sisters, unless needed in case of illness, when application is to be made by them to the Superintendent, who will grant the request, reporting the same to the Committee. This plan is proposed by the Ladies, in consequence of circumstances which have been brought before their consideration". ${ }^{130}$ Tea, coffee or cocoa were to be drunk on night duty. Spirits and malt liquor were to be consumed only with the consent of the doctor who attended the nurses' Home. Sisters who had minor ailments were not permitted to take brandy without the approval of a doctor or the Ladies' Committee, who advised them to take ginger instead. ${ }^{131}$ When spirits were found in a sister's room, she was not disciplined because there was said to be "no supporting evidence". ${ }^{132}$ However, invalid nurses unable to attend breakfast were permitted to receive bitter ale at 11 a.m., and those who were fit enough were expected to assist the poor in the neighbourhood. ${ }^{133} \mathrm{~A}$ comment was made that one nurse was unable "to make little things fit for invalids", suggesting that they were expected to employ their spare time for the benefit of their employer as a domestic servant would, mending the household linen. ${ }^{134}$

Many of the causes of dismissal were alcohol-related, and problems relating to drinking recur throughout the minutes. Sisters seen to enter and partake in a public house disgraced themselves and the Institution. They were fortunate to have been reproved but not dismissed. Following this incident, a letter expressing the displeasure of the Ladies' Committee would be read to all the sisters. ${ }^{135}$ Sister Turner, having shown "a great want of sobriety", was less fortunate and was dismissed, as were Sister Holland for coming home in a state of intoxication and another sister who was intoxicated when attending her patient. ${ }^{136}$ Yet in 1844 the Committee decided that "the common draft porter is to be kept in the house". ${ }^{137}$ It was very likely that inflicting their policy of total abstinence had proved to be both unreasonable and unworkable.

Although it was suggested that three serious charges of misconduct would warrant dismissal, ${ }^{138}$ no grace was given to infringements involving stealing. A sister was dismissed for taking a dead patient's slippers, described as a most unpleasant charge. Another sister who claimed a dead patient's clothes and accepted a gift of $£ 5$ was also dismissed. ${ }^{139}$

\footnotetext{
${ }^{129}$ Rules and Regulations, SA/QNI/W.1/4; minutes of the Ladies' Committee, SA/QNI/W.2/ 1, 16 Sept. and 1 Oct. 1841; SA/QNI/W.2/3, 1 Sept. 1848, 12 Sept. 1851.

${ }^{130}$ Minutes of the Ladies' Committee, SA/ QNI/W.2/1, 11 Mar. 1842; SA/QNI/W.2/2, 6 June 1845; SA/QNI/W.2/4, 9 Apr. 1858; Bye-laws of the Institution of Nursing Sisters, SA/QNI/W.1/5.

${ }^{131}$ Rules and Regulations, SA/QNI/W.1/4; minutes of the Ladies' Committee, SA/QNI/W.2/ 4, 26 Jan. 1855.

${ }^{132}$ Minutes of the Ladies' Committee, SA/ QNI/W.2/2, 6 June 1845.
}

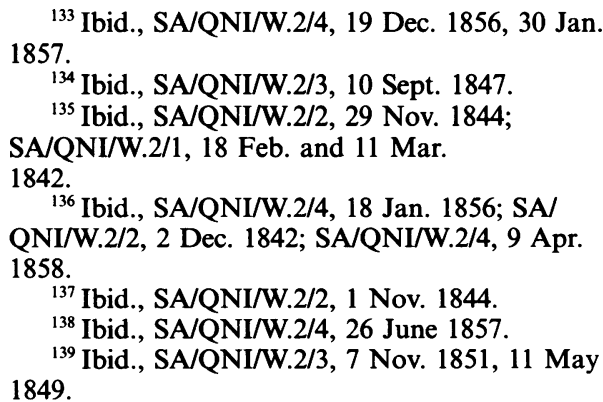




\section{$R$ G Huntsman, Mary Bruin and Deborah Holttum}

Apart from "an inexpensive book", the sisters had to solemnly promise not to accept gifts from grateful patients or their relatives, and to "candidly mention to the Committee any present that may be offered to them". Any sister who accepted a legacy forfeited her right to the superannuation fund. ${ }^{140}$ Sister Henderson, who worked on the district, accepted $£ 1$ and was told her contract would not be renewed if it was not returned. ${ }^{141}$ The widely accepted practice of receiving mourning, a gift commonly given when a patient died, was specifically forbidden. Offenders faced dismissal or a demand that the money be returned. ${ }^{142} \mathrm{~A}$ sister, with a bad temper, who accepted mourning and a legacy of $£ 30$ was dismissed. ${ }^{143}$

Although at the time probably generous, treatment of injured or ill nurses was, by present-day standards, harsh. Nurses who were unfit to work for the Institution were compensated or, if possible, found other employment. A nurse who, in 1846, complained of a back injury was provided with a supporting belt by the Committee. ${ }^{144}$ In 1848, the Institution agreed to pay half the expenses of medicines required by the nurses, and a few simple remedies would be kept in the Home, but it was ten years before the Committee agreed that surgical supports, rendered necessary by the work, would be supplied gratis. ${ }^{145} \mathrm{~A}$ sister who complained of damaging her hands was given $£ 1$, and another, leaving because she had lost her health "whilst in the service of the house", was given $£ 210 \mathrm{~s}$. $0 \mathrm{~d} .{ }^{146}$ A sister whose arm made her unfit to continue at the Institution was advised to take a job as a sister at St Thomas's Hospital, and it was arranged that another sister "in poor health" should go as head nurse to the Invalid Asylum in Stoke Newington. ${ }^{147}$

In 1845 , it was decided that work in a men's accident ward was not suitable. ${ }^{148}$ Even in 1869, Guy's Hospital preferred to post married women to male wards, a nicety that the Institution, with only a few suitable widows in their employ, found hard to implement. ${ }^{149}$ If possible, alternative employment would be provided if a posting proved too arduous, Sister West remaining at the London Hospital after a smaller and lighter ward had been offered to her. Sisters Vilven and Lang were allowed to leave the Hon. Miss Hill. It was felt to be unreasonable that "so great a demand of strength should be made on the Sisters". ${ }^{150}$ The Ladies' Committee was capable of sympathy. Sister Davis, a former employee, was reported to be in great distress through want of work, which was then offered to her. They acknowledged

\footnotetext{
${ }^{140}$ Bye-laws of the Institution of Nursing Sisters, SA/QNI/W.1/5; minutes of the Ladies' Committee, SA/QNI/W.2/4, 12 Oct. 1855.

${ }^{141}$ Minutes of the Ladies' Committee, SA/ QNI/W.2/4, 4 Jan. 1856.

${ }^{142}$ Bye-laws of the Institution of Nursing Sisters, SA/QNI/W.1/5; minutes of the Ladies' Committee, SA/QNI/W.2/3, 7 July 1848, 16 July 1847.

${ }^{143}$ Minutes of the Ladies' Committee, SA QNI/W.2/4, 22 Sept. 1855.
}

\footnotetext{
144 Ibid., SA/QNI/W.2/2, 29 Jan. 1846.

${ }^{145}$ Ibid., SA/QNI/W.2/3, 1 Sept. 1848; SA/ QNI/W.2/4, 9 Nov. 1856.

${ }^{146}$ Ibid., SA/QNI/W.2/4, 25 Aug. 1854, 15

May 1857.

${ }^{147}$ Ibid., SA/QNI/W.2/4, 2 Oct. 1857; SA/QNI/

W.2/3, 16 Feb. 1849.

${ }^{148}$ Ibid., SA/QNI/W.2/2, 5 Dec. 1845.

${ }^{149}$ Steele, op. cit., note 55 above, p. 552.

${ }^{150}$ Minutes of the Ladies' Committee, SA/ QNI/W.2/1, 3 June 1842; SA/QNI/W.2/3, 12 Mar. 1852.
} 


\section{The Contribution of Elizabeth Fry to Nursing Reform}

the service of a sister who left after twelve years by presenting her with a Bible, and a servant, Mary, received a sovereign for faithful service in the home. ${ }^{151}$

The disciplinary problems that haunted the Committee were not confined to the sisters. In 1843, after the superintendent resigned, the Ladies' Committee decided it was now necessary to have rules for their matron, who was strongly recommended to attend her own place of worship on a Sabbath and, if possible, on weekdays. ${ }^{152}$ Some years later, on 25 October 1857, after "long and serious consideration" at a quarterly meeting held off-site, the superintendent was dismissed and articles were noted to be missing. Her claim for salary, board, lodging and washing until 25 June 1858 was settled, after legal advice, with a payment of $£ 71 . .^{153}$

\section{Nature of Nursing Duties}

For a short time after its foundation, the Institution permitted the care of lyingin cases but, in 1842, Guy's Hospital requested that, except in emergencies, no maternity work be undertaken. ${ }^{154}$ Fear of spreading infection was very real; Guy's annual report for 1869 specifically stated that with 1,929 mothers delivered, there were five deaths, but none from puerperal infection. ${ }^{155}$ Nurses were still frequently sent to nursing homes and also to boarding schools and residential institutions where outbreaks of infectious diseases had occurred. At that time, "infectious diseases" were commonly lethal. In 1844, an outbreak of scarlet fever caused the death of Elizabeth Fry's son William and two of his children. The servants, as they sickened, were transferred to Guy's Hospital and the sisters from the Institution were provided to nurse them there. ${ }^{156}$ After nursing an infectious case, the sister spent two weeks in lodgings in quarantine to reduce the risk of spreading infection to either the Mother House or to another posting. In 1854, plans were put in hand to obtain a small house specifically for this purpose. ${ }^{157}$

\section{Hospital Nursing}

A number of hospitals applied to the Institution for nurses and their applications were carefully considered by the Ladies' Committee. In reaching a decision as to the suitability of a hospital, the Committee essentially carried out the first audit/inspection of English hospitals by an independent outside agency. The refusal of the prestigious Institution of Nursing Sisters to supply nursing staff because of unsatisfactory working conditions or salary, must have been

\footnotetext{
${ }^{151}$ Ibid., SA/QNI/W.2/4, 26 Sept. 1856, 26 Feb. 1858, 26 Oct. 1855. 1843.

${ }_{152}$ Ibid., SA/QNI/W.2/2, 18 Aug. and 7 Oct.

${ }_{153}$ Ibid., SA/QNI/W.2/4, 25 Oct. 1857, 29 Jan. 1858.

${ }_{154}$ Ibid., SA/QNI/W.2/1, 12 Mar. 1841, 11

Mar., 9 and 23 Sept. 1842.
}

\footnotetext{
${ }^{155}$ Steele, op. cit., note 55 above, p. 540 .

${ }^{156}$ Fry and Cresswell, op. cit., note 4 above, vol. 2, p. 496.

${ }^{157}$ Minutes of the Ladies' Committee, SA QNI/W.2/2, 28 Mar. and 21 Nov. 1845; SA/QNI/ W.2/3, 11 Nov. 1853; SA/QNI/W.2/4, 19 May 1854.
} 


\section{R G Huntsman, Mary Bruin and Deborah Holttum}

embarrassing to a hospital's governing body and provided a powerful impetus for improvement.

The problems that arose with the London Hospital are worth detailed examination because the complaints by the Ladies' Committee and the hospital's response to these have been recorded in detail. In March 1842, the Ladies' Committee agreed to supply a head nurse to the London Hospital at $£ 22$ per annum. They reserved the right to change the nurse in six months. ${ }^{158}$ On 14 June 1842, the London expressed a wish to pay the Institution sisters directly. The Ladies' Committee recognized that they would lose control over their employees if they permitted them to be paid by an outside employer and they arranged to meet the hospital's House Committee. On 1 July, the request of the London Hospital to pay the Institution nurses directly was refused. ${ }^{159}$ This incident may well have precipitated what was to follow.

On 15 July, the minutes of the Ladies' Committee record, "Great complaint having been made by the Nursing Sisters in the London Hospital of the uncleanly state of that Establishment, the Secretary is desired by the Committee to inform the Committee of the London Hospital that unless an improvement be made the Nursing Sisters cannot be allowed to continue on duty there". On 29 July, the probationer, Sister Horwood, was withdrawn, Sister Cornish staying on for a short time to complete her contractual arrangements and then for a further fortnight at the special request of the matron of the hospital. ${ }^{160}$

The General Committee Report Book (Report of the House Committee to the Governors) to be presented to the Quarterly General Court (1 June 1842) recommended: whitewashing the wards; the matron to be instructed to see that annual ward cleaning was properly carried out; wards to be repaired; repainting of exterior and interior ironwork and woodwork "not having been painted for several years". ${ }^{161}$ On 5 July the General Court (Governors) Minute Book acknowledged overcrowding in the wards "to a degree unfavourable to recovery". ${ }^{162}$

The Ladies' Committee had planned to move the Nurses' Home at Raven Row, adjacent to the London Hospital, to a more central location in March 1842, before any hint of problems appeared in the minutes. ${ }^{163}$ The promises of future improvements at the hospital did not affect the Committee's decision to sever their special relationship with the London in favour of Guy's Hospital "who granted them the advantages of that admirable Institution". ${ }^{164}$

As the minutes of the Ladies' Committee show, the Institution of Nursing Sisters received numerous requests from hospitals for their nurses. The first request for a

\footnotetext{
${ }^{158}$ Ibid., SA/QNI/W.2/1, 28 Mar. 1842.

${ }^{159}$ Minutes of the House Committee, op. cit., note 87 above, 14 June 1842; minutes of the Ladies' Committee, SA/QNI/W.2/1, 21 June and 1 July 1842.

${ }^{160}$ Minutes of the Ladies' Committee, SA/QNI/W.2/1, 15 and 29 July, 26 Aug. 1842.
}

\footnotetext{
${ }^{161}$ General Committee Report Book, op. cit., note 87 above, 1 June 1842 .

${ }^{162}$ General Court Minute Book, op. cit., note 87 above, 5 July 1842 .

${ }^{163}$ Minutes of the Ladies' Committee, SA/ QNI/W.2/1, 11 Mar. 1842.

${ }^{164}$ Report of the Institution for Nursing Sisters, op. cit., note 35 above, p. 8 .
} 


\section{The Contribution of Elizabeth Fry to Nursing Reform}

sister, received in May 1841, was for a head nurse at Lynn Hospital, King's Lynn, Norfolk, ${ }^{165}$ a town often visited by Elizabeth Fry. The Institution decided that they would send a nurse "if one can be found of suitable qualification". The personal wishes of Mrs Fry were not always acceded to. In 1842, the Ladies' Committee decided that they were unable to offer accommodation to two matrons awaiting the sailing of convict vessels to Australia, although the provision of matrons to accompany the female convicts was a project dear to Mrs Fry's heart. ${ }^{166}$

There was a lack of efficient nurses at Guy's Hospital. After four requests none were available to be sent, a decision that resulted in great dissatisfaction. ${ }^{167}$ An application for a nursing sister for the Hospital for Consumption and Diseases of the Chest was turned down because of the nature of the duties required (scouring the ward, etc.), combined with the low salary. A later minute reported that Sister Leitz had worked at the Consumptive Hospital for two years, suggesting an accommodation had been reached with the hospital. ${ }^{168}$

After enquiries by Lady Inglis, an application from the chaplain of the Middlesex Hospital for nursing sisters was rejected because "the nature of the duties required and the small payment render the employment of sisters there undesirable". ${ }^{169} \mathrm{~A}$ request from the Royal Infirmary Manchester for a sister for the female surgical ward was successful, despite the low salary of $£ 25$ per annum, "Placing the Sisters in hospitals being desirable, it is accepted and a Sister to be sent as soon as can be arranged". ${ }^{170}$ Regarding a request from the Manchester Union (workhouse) for a sister to instruct the inmates in nursing, the Committee would be pleased to oblige but required further details. ${ }^{171}$

The Royal Infirmary Manchester's application suggests that the Committee felt they had some responsibility to supply hospital nurses, although Adelaide Nutting and Lavinia Dock, writing in 1907, reported that by 1857 (the year after the Crimean War ended) all ninety sisters trained by the Institution were engaged in private duties. ${ }^{172}$ While not totally true, the minutes of the Ladies' Committee suggest that the number of nurses sent by the Institution to hospitals remained small (except during periods of conflict), ${ }^{173}$ hardly balancing the number they recruited from active hospital nursing staff. For example, on 17 April 1846, they received a candidate from Guy's Hospital and on 1 May they sent a nurse as a supernumerary sister to the same hospital. ${ }^{174}$

Apart from the improvement of hospital working conditions that resulted from the attentions of the Ladies' Committee, the Institution had a negligible impact on the provision of hospital nurses.

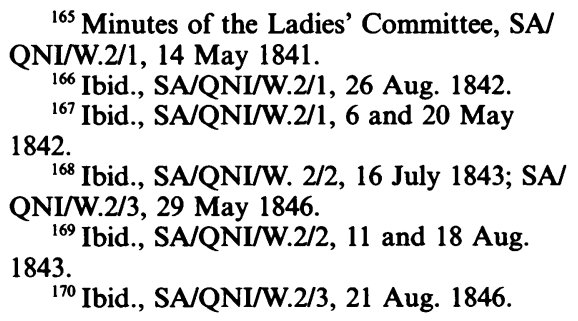

${ }^{165}$ Minutes of the Ladies' Committee, SA QNI/W.2/1, 14 May 1841.

${ }^{166}$ Ibid., SA/QNI/W.2/1, 26 Aug. 1842.

${ }^{167}$ Ibid., SA/QNI/W.2/1, 6 and 20 May 1842.

${ }^{168}$ Ibid., SA/QNI/W. 2/2, 16 July 1843; SA/ QNI/W.2/3, 29 May 1846. 1843.

${ }^{169}$ Ibid., SA/QNI/W.2/2, 11 and 18 Aug.

${ }^{170}$ Ibid., SA/QNI/W.2/3, 21 Aug. 1846.

\footnotetext{
${ }^{171}$ Ibid., SA/QNI/W. 2/3, 16 Feb. 1849.

${ }^{172}$ Nutting and Dock, op. cit., note- 15 above, vol. 2 , p. 76.

${ }^{173}$ Minutes of the Ladies' Committee, SA/ QNI/W.2/1, 28 Mar. 1842; SA/QNI/W.2/2, 28 Mar. and 5 Dec. 1845; SA/QNI/W.2/3, 1 May 1846, 23 Apr. 1847; SA/QNI/W.2/4, 21 Apr. and 30 June 1854, 16 Oct. 1857. 1846.
} 


\section{R G Huntsman, Mary Bruin and Deborah Holttum}

\section{Charitable Activity: District Nursing}

As a result of careful housekeeping and the steady accumulation of capital, the purse-strings of the Institution were loosened to permit their nurses to undertake charitable work for both institutions and individuals. As early as 1848, it was reported that there were about twenty-eight nurses employed, and during the period August 1845 to March 1848, 366 cases of sickness were attended. No charge was made for 30 of these cases and the charges levied for 92 were insufficient to remunerate the Society. ${ }^{175}$

In 1844, the Ladies' Committee considered the terms on which a nursing sister could be obtained for "the Clergy's daughter Asylum at Clifton", and what kind would be required. ${ }^{176}$ Having earlier decided that support would not be continued permanently, in April 1853 the provision of a gratuitous sister to the Chandos Institution, a nursing home for distressed gentlewomen, was reconsidered because of "fresh arrangements likely to be made there". ${ }^{177}$ Shortly after, the Chandos Institution moved to Upper Harley Street, with Florence Nightingale taking charge in August. These impending changes must have been known to the President of the Ladies' Committee, Lady Inglis, a friend of the Nightingale family.

In 1854, a nurse was supplied again without charge to another charitable organization, the Institution for Destitute Girls. ${ }^{178}$ Payment of fees were also waived or reduced for individual needy cases; the wife of a policeman being given a nurse free of charge, and a Mrs Lambert supplied with a nurse at the reduced fee of 7 shillings a week. It was not thought appropriate to send a sister to attend "a poor blind girl". ${ }^{179}$

The care of the sick poor was not attractive to all nurses but it was not until 1857 that, following a complaint that one of their nurses had been accused of failing in kindness in a poor case, the Ladies' Committee admitted that often great difficulties arose when nurses were sent to the very poor. ${ }^{180}$ As early as 1841 , a request was received from Dr West for a sister to be attached to the Finsbury Dispensary, a charitable institution, where medicines were dispensed and medical advice given gratis, or for a small charge. Lodgings at the dispensary or with a family at the centre of the dispensary district would be provided by Dr West. It was envisaged that with instructions left by a physician or surgeon, the sister would act more as an instructress in simple nursing and invalid cooking than as a nurse. Cautiously, unsure whether the means of the Institution were sufficient, the Ladies' Committee enquired about the salary required. ${ }^{181}$ It appears that no action was taken, either because at that time there was no willing nurse to send or because of financial insecurity.

\footnotetext{
${ }^{175}$ Report of the Institution for Nursing Sisters, op. cit., note 35 above, p. 6.

${ }^{176}$ Minutes of the Ladies' Committee, SA QNI/W.2/2, 3 May 1844.

${ }^{177}$ Ibid., SA/QNI/W.2/3, 31 Jan. 1851, 28 Feb. 1851, 29 Apr. and 8 July 1853.
}

\footnotetext{
${ }^{178}$ Ibid., SA/QNI/W.2/4, 1 Dec. 1854.

${ }^{179}$ Ibid., SA/QNI/W.2/4, 7 Aug. and 24 July 1857; SA/QNI/W.2/3, 11 Oct. 1850.

${ }^{180}$ Ibid., SA/QNI/W.2/4, 13 Nov. 1857. 1841 .
} 


\section{The Contribution of Elizabeth Fry to Nursing Reform}

The Institution appears to have been stung into seriously entering the field of district nursing following the receipt of a letter in 1847 from a Mr Lang or Long saying that it should provide more nurses for the poor and middle classes. The minutes record that the Committee agreed that this was indeed the object of the Institution-although they were clearly not fulfilling it. ${ }^{182}$ Following this rebuke, a section devoted to nursing the poor developed and became established over the next few years. The Institution minutes of 1849 report that "it has been suggested that one or two nurses should be employed exclusively amongst the Poor and that Mrs Langford should be engaged for this purpose". Articles for sickness would be kept in the Home. ${ }^{183}$ In 1854, after some years' experience, it was agreed that the Institution would provide the salary and dress for the sisters and the parish would supply the lodging expenses, the sisters being superintended by the clergyman of the parish. ${ }^{184}$

In 1853, the Committee decided "to engage a poor woman for cleaning to assist the sick poor" thus clearly differentiating the domestic from the nursing aspects of the sisters' work, a condition of employment they were also demanding for them in hospitals. ${ }^{185}$ It would appear that, by 1854 , a small, well organized and effective district nursing service had been established together with the loan of sheets and clothes for the sick poor made up from material procured for that purpose. ${ }^{186}$ The 1848 report of the Institution of Nursing Sisters also approved widening their activities beyond private nursing. Nursing the poor was an area "it hopes to see more extensively carried out". ${ }^{187}$

\section{Conclusion}

The change from the slatternly Sarah Gamp to the trained nurse emerging from the Victorian nursing schools was completed with explosive force within a period of about forty years. This can partly be explained by the intricate relationships that developed between the numerous reformers. It is this synergy, especially that between Pastor Fliedner and Elizabeth Fry, that this article has attempted to emphasize (see Figures 5 and 6).

Drawing on the earlier experience of Kaiserswerth, Elizabeth Fry and her Institution of Nursing Sisters established in England an early nineteenth-century secular health care delivery programme run efficiently by women. The staff were all Protestant and wore a uniform; they were based in a residential nurses home to which men were not allowed entry, and the consumption of alcohol was kept within certain limits. Protestant nursing recruits were upgraded through a formal selection procedure based on references and interviews. Literacy was obligatory. Pay and working conditions were equal or superior to domestic service, the major employment

\footnotetext{
${ }^{182}$ Ibid., SA/QNI/W.2/3, 13 Aug. 1847.

${ }^{183}$ Ibid., SA/QNI/W.2/3, 26 Oct. 1849. 1854.

${ }^{184}$ Ibid., SA/QNI/W.2/4, 20 Oct. and 17 Nov.

${ }^{185}$ Ibid., SA/QNI/W.2/3, 2 Sept. 1853. SA/

QNI/W.2/2, 16 July, 11 and 18 Aug. 1843.
} 


\section{St. Vincent de Paul (1581-1660)}

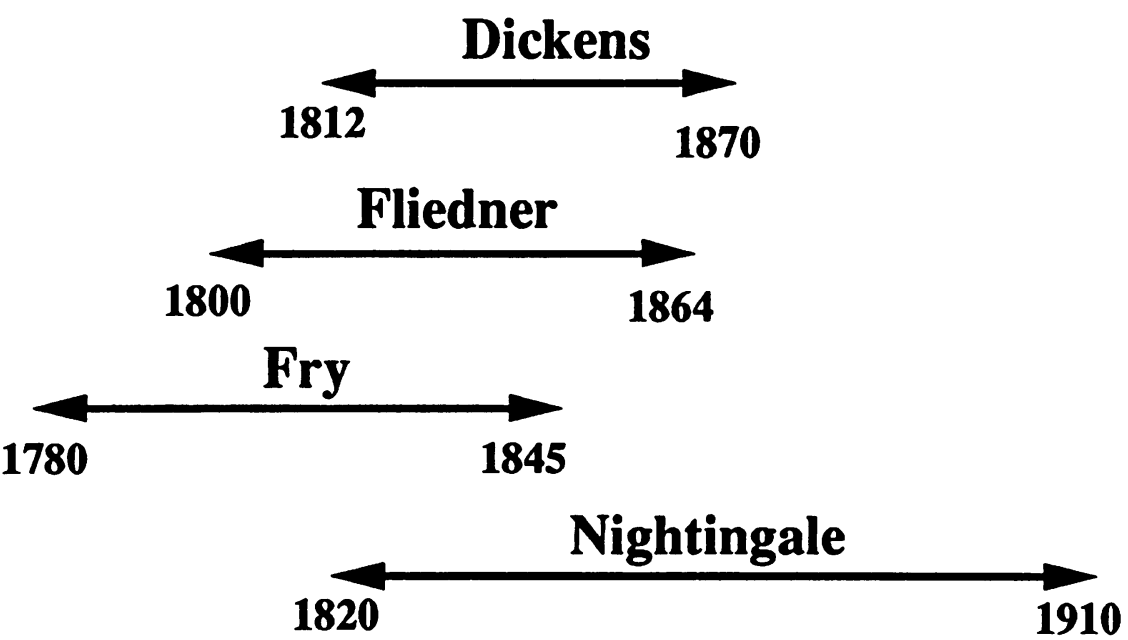

Figure 5: With the exception of St Vincent de Paul, the lifespan of the major participants in nursing reform overlap. This permitted the synergy that developed between them.

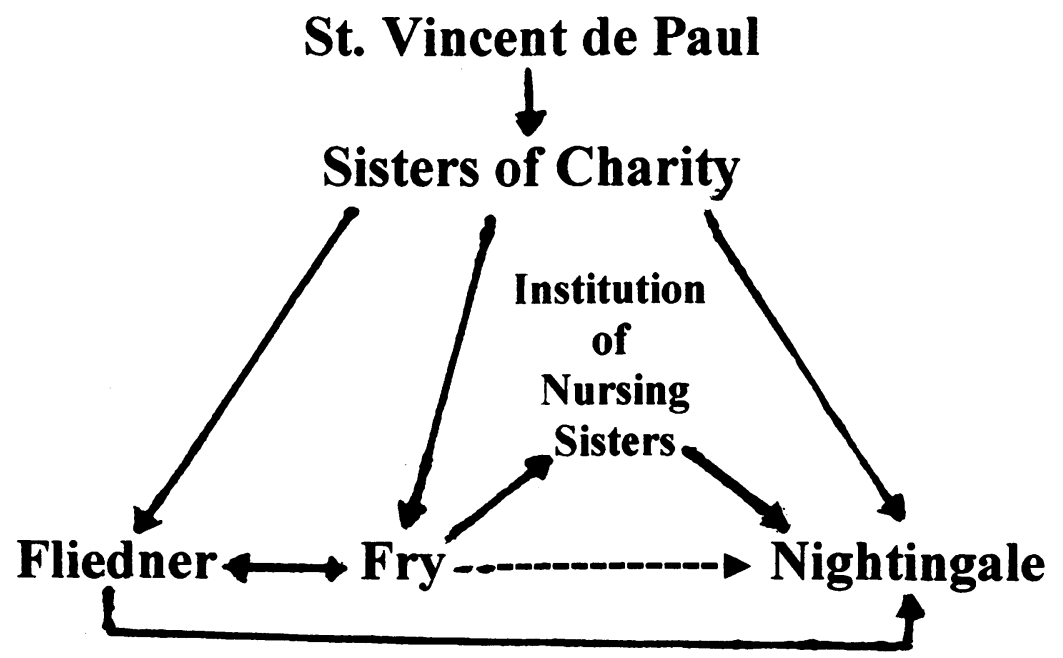

Figure 6: The complex interaction between those involved in nursing reform is displayed. Note the central position of Elizabeth Fry. Because written proof of direct contact, although likely, is lacking, the figure shows only an indirect link between Elizabeth Fry and Florence Nightingale. (See Sarah A Tooley, The life of Florence Nightingale, 5th ed., London, S H Bousfield, 1908, pp. 46-51.) 


\section{The Contribution of Elizabeth Fry to Nursing Reform}

opportunity for women at that time, and the source of many Institution nurses. A three-year contract was renewable when service was satisfactory. In 1847, a superannuation fund was set up for long-service nurses. Hospital training was provided, albeit initially of only three months, with formal evaluation; and further specialized hospital training given, if the Institution required it. Private employers supplied performance evaluations of the nursing staff. In hospitals, inspections and enquiries by the Institution of Nursing Sisters-an independent authority-ensured acceptable working conditions for seconded nursing staff. The Institution supplied organized district and charitable nursing as well, and ensured that domestic and nursing duties were clearly separated. Disciplinary decisions were taken by a management committee to which all nursing staff had access. Health care for ill nursing staff was provided. An important indication of the Institution's status was Queen Adelaide's patronage, which marked the beginning of royal interest in the nursing profession.

\section{Why has Elizabeth Fry been Forgotten?}

The fact that Elizabeth Fry's contribution to nursing reform is largely forgotten is the fault of her two daughters, who chose to devote only three out of 1,061 pages in their 1847 biography to her work in this area. ${ }^{188}$ This concentration on Elizabeth Fry's work on penal reform, at the expense of her pioneer work in nursing reform has been perpetuated by the numerous biographers that followed. Not surprisingly, Elizabeth Fry, together with Pastor and Mrs Fliedner and many others, have been denied the recognition they deserve in this country.

In the eyes of many, including the eminent surgeon Sir James Paget, the contribution of Florence Nightingale, by comparison with Elizabeth Fry, was self-evident. In 1885 he described the changes he had personally witnessed over the last fifty years in the wards of St Bartholomew's Hospital: "Miss Nightingale showed what might be done in hospitals by highly cultivated, courageous and benevolent gentlewomen; and the noble example which she showed had, I think, more influence than anything else that can be told-of in the production of the happy changes in the midst of which you work". ${ }^{189}$

Miss Nightingale's quite extraordinary charisma inadvertently dimmed those who preceded her. To sustain sagging morale in the Crimean War, the country needed a heroine and, in Miss Nightingale, a heroine was at hand. As a result, the universal recognition of her contribution to nursing contrasts with the lack of public awareness of the work of Elizabeth Fry's Institution of Nursing Sisters.

Who then was the "founder of nursing"; "the real pioneer of Nursing in this country"? Despite the fact that circumstances permitted Elizabeth Fry only limited influence on reform in hospital nursing, an area she left to Florence Nightingale, few would deny her these accolades. At a meeting of the Ladies' Committee of the Institution of Nursing Sisters held after the death of Mrs Fry in 1845, those present

\footnotetext{
${ }^{188}$ Fry and Cresswell, op. cit., note 4 above, vol. 2, pp. 373-5.

${ }^{189}$ Paget, op. cit., note 24 above, pp. 353-4.
} 


\section{$R$ G Huntsman, Mary Bruin and Deborah Holttum}

expressed the wish that "this society may become one of the many monuments of her excellence". ${ }^{190}$ It is hoped that this paper, by drawing attention to this quite remarkable organization and the equally remarkable woman who founded it, will help to achieve their desire.

${ }^{190}$ Minutes of the Ladies' Committee, SA/ QNI/W.2/2, 23 Oct. 1845. 